\title{
The contribution of trees and grasses to productivity of an Australian tropical savanna
}

\author{
Caitlin E. Moore ${ }^{1}$, Jason Beringer ${ }^{2,1}$, Bradley Evans ${ }^{3,4}$, Lindsay B. Hutley ${ }^{5}$, Ian McHugh ${ }^{1}$, and Nigel J. Tapper ${ }^{1}$ \\ ${ }^{1}$ School of Earth, Atmosphere and Environment, Monash University, VIC, 3800, Clayton, Australia \\ ${ }^{2}$ School of Earth and Environment, University of Western Australia, WA, 6009, Crawley, Australia \\ ${ }^{3}$ Department of Environmental Sciences, The University of Sydney, NSW, 2015, Eveleigh, Australia \\ ${ }^{4}$ Terrestrial Ecosystem Research Network Ecosystem Modelling and Scaling Infrastructure, \\ The University of Sydney, NSW, 2015, Eveleigh, Australia \\ ${ }^{5}$ School of Environment, Research Institute for the Environment and Livelihoods, \\ Charles Darwin University, NT, 0909, Casuarina, Australia
}

Correspondence to: Caitlin E. Moore (caitlin@moorescience.com.au)

Received: 11 November 2015 - Published in Biogeosciences Discuss.: 7 December 2015

Revised: 11 April 2016 - Accepted: 12 April 2016 - Published: 26 April 2016

\begin{abstract}
Savanna ecosystems cover $20 \%$ of the global land surface and account for $25 \%$ of global terrestrial carbon uptake. They support one fifth of the world's human population and are one of the most important ecosystems on our planet. Savanna productivity is a product of the interplay between trees and grass that co-dominate savanna landscapes and are maintained through interactions with climate and disturbance (fire, land use change, herbivory). In this study, we evaluate the temporally dynamic partitioning of overstory and understory carbon dioxide fluxes in Australian tropical savanna using overstory and understory eddy covariance measurements. Over a 2-year period (September 2012 to October 2014) the overall net ecosystem productivity (NEP) of the savanna was $506.2( \pm 22 \mathrm{SE}) \mathrm{g} \mathrm{C} \mathrm{m}^{-2} \mathrm{yr}^{-1}$. The total gross primary productivity (GPP) was $2267.1( \pm 80 \mathrm{SE}) \mathrm{g} \mathrm{C} \mathrm{m}^{-2} \mathrm{yr}^{-1}$, of which the understory contributed $32 \%$. The understory contribution was strongly seasonal, with most GPP occurring in the wet season (40\% of total ecosystem in the wet season and $18 \%$ in the dry). This study is the first to elucidate the temporal dynamics of savanna understory and overstory carbon flux components explicitly using observational information. Understanding grass productivity is crucial for evaluating fuel loads, as is tree productivity for quantifying the tree carbon sink. This information will contribute to a significant refinement of the representation of savannas in models, as well as improved understanding of relative tree-grass productivity and competition for resources.
\end{abstract}

\section{Introduction}

Savannas are one of the most important ecosystems on our planet due to their vast spatial extent, productivity and rich biodiversity. They are characterised by the coexistence of a discontinuous tree canopy and a more uniformly distributed grassy understory (Scholes and Archer, 1997; House and Hall, 2001; Bond, 2008) and occur in tropical and subtropical regions with a strong seasonal climate. Savannas span $20 \%$ of the global land surface and account for around $25 \%$ of total gross primary production (GPP), making them one of the most important ecosystem sinks of carbon on the planet (Saugier et al., 2001; Grace et al., 2006; Beer et al., 2010; Ryu et al., 2011). This productivity directly translates into biomass accumulation, leading to carbon storage in the tree component and fuel to support herbivory and fire from the grass component. As a result, savannas are an important source of food and income (via grazing) for roughly a quarter of the world's human population (Scholes and Archer, 1997; Mistry, 2001), as well as an important resource for timber harvesting (Shackleton et al., 2002) and carbon sequestration (Beringer et al., 2007; Kanniah et al., 2011; Lehmann et al., 2014).

Savanna productivity is controlled by wet season duration and growing season length, the annual solar radiation budget, amount and distribution of precipitation, and variation in temperature and cloud cover (Nemani et al., 2003; Kan- 
niah et al., 2010). Arguably, the most important factor limiting productivity is water availability, which has been well documented in the literature over the last 40 years (Scholes and Archer, 1997; House and Hall, 2001; Sankaran et al., 2004, 2005; Ma et al., 2007; Garbulsky et al., 2010; Kanniah et al., 2010, 2011). Seasonal moisture variability causes soil water potentials to increase above the plant wilting point at all soil depths during the wet season but fall below wilting point in the dry season (Sarimento, 1996). This has a direct influence on plant lifecycles and savanna productivity. For example, evergreen woody species adopt a phenological strategy where they invest in root systems to access deeper soil moisture stores in order to remain physiologically active for most, if not all, of the year (O'Grady et al., 1999; Hutley et al., 2000). Alternatively, deciduous plants adopt a phenological strategy where they remain dormant through times of water stress as a drought avoidance tactic (Eamus and Prichard, 1998; Eamus, 1999). Grass species typically opt for an annual or perennial phenology as a similar tactic to avoid drought (Andrew and Mott, 1983; Prior et al., 2006; Bond, 2008).

Savannas occupy latitudes close to the equator (between $30^{\circ} \mathrm{N}$ and $\mathrm{S}$ ), so they receive a large amount of solar radiation year round leading to minimal variability in air temperature. Kanniah et al. (2011) showed this to exert little effect on savanna productivity. Yet diffuse radiation is known to penetrate the tree canopy more than direct radiation (Roderick et al., 2001), which should be beneficial to productivity. However, high variability in cloud cover and atmospheric aerosols in the wet and dry season changes the portion of direct and diffuse radiation reaching the land surface (Allen et al., 2008; Kanniah et al., 2013), which has a direct influence on available solar radiation to support productivity. A modelling study from Whitley et al. (2011) suggests savanna productivity can be light limited due to a finite capacity of the vegetation to intercept light given limited canopy cover development. It is clear then that savanna productivity is regulated by a complex interaction of physiological and environmental drivers. The extent to which these drivers influence tree and grass productivity individually has remained largely unexplored (Whitley et al., 2011).

Fire is another fundamental driver of productivity and carbon storage in savannas (Beringer et al., 2007, 2015; Bond, 2008). High fire frequency and/or fire severity affects plant demographics (hence carbon storage) by reducing tree growth rates and recruitment of juveniles into the mature adult stand (Murphy et al., 2010; Hoffmann et al., 2012; Werner and Prior, 2013). When fire is excluded from savannas, woody thickening and forest encroachment into the savanna boundary can occur (Hoffmann et al., 2012). Scheiter and Higgins (2009) demonstrated this phenomenon using a dynamic global vegetation model where fire was essentially "switched off" in an African savanna, revealing tree dominance increased along with a $13 \%$ rise in biomass. At the global scale, savannas contribute $44 \%$ to total biomass fire emissions (van Der Werf et al., 2010). Therefore, investigating tree-grass productivity dynamics in savannas is ever important for fire management and carbon cycle understanding (Beringer et al., 2015; Scheiter et al., 2015).

In Australia, whilst much is known about the drivers of savanna ecosystem GPP (Beringer et al., 2003, 2007; Kanniah et al., 2011; Whitley et al., 2011), little is known about the relative contributions of tree and grass productivity, or of their spatial and temporal dynamic (Whitley et al., 2011). Much of the spatial variability in the relative cover fractions of trees and grass is thought to be due to annual rainfall, which defines woody cover and subsequent grass production. The large spatial variation in grass productivity leads to high (1-3 year) fire frequency (Russell-Smith and Yates, 2007; Beringer et al., 2015) that feeds back to control woody plant demographics. Fire typically consumes cured grass biomass, top kills juvenile trees and scorches the bark and leaves of mature canopy trees (Prior et al., 2006; Werner and Franklin, 2010; Werner and Prior, 2013). This in turn changes the savanna productivity balance from a sink to a source of carbon as the tree canopy uses its carbon resources to re-establish lost canopy biomass at a temporary loss of photosynthetic capacity (Beringer et al., 2003, 2007; Cernusak et al., 2006).

While fire is the most recurrent disturbance in these savannas, wind storms and cyclones common to this region also cause damage on longer timescales, altering tree-grass productivity (Staben and Evans, 2008; Hutley et al., 2013). Disturbance also arises from biomass grazing of feral buffalo (Werner et al., 2006) and termites (Werner and Prior, 2007; Jamali et al., 2011), which feeds back into the productivity balance of Australian savannas. Taking these disturbances into account, it is estimated that savanna accounts for $33 \%$ of terrestrial carbon stored in Australia (Williams et al., 2004). It is therefore important to understand the partitioning of productivity in these systems in order to understand how they may respond to climatic drivers and future environmental change. Australian savannas provide a great opportunity to do this as they are the most pristine and intact savannas in the world (Mackey et al., 2007).

To understand the consequences of future environmental change for savannas it is important to first understand how the trees and grasses contribute individually to savanna productivity, as well as how they individually and jointly respond to environmental drivers and disturbance. In this paper we use eddy covariance data with the aim to understand the temporal dynamics of tree and grass productivity in an Australian tropical savanna. Two flux towers (understory and overstory) were used to partition GPP between the trees and the grasses for a typical mesic savanna site in northern Australia. Our objectives were to (i) validate the use of a flux tower in the understory in a savanna; (ii) estimate the annual net ecosystem production (NEP) of the savanna and partition it into tree and grass contributions; and (iii) estimate annual overstory and understory GPP and respiration and how they vary seasonally. This research will provide observational in- 
formation about tree-grass productivity dynamics in an Australian savanna, which will be highly useful for improving and validating model outputs that currently struggle to get savanna dynamics right.

\section{Methods}

\subsection{Site description}

To achieve our aims we utilised data collected at the longterm Howard Springs OzFlux site $(-12.4942$, 131.15325, http://www.ozflux.org.au/). This site is representative of mesic savanna that occurs in the northern region of Australia, where annual rainfall exceeds $1200 \mathrm{~mm}$. Howard Springs has been the subject of many studies that began in the late 1990s examining patterns of carbon and water flux from the savanna ecosystem (Cook et al., 1998; O'Grady et al., 1999; Hutley et al., 2000; Eamus et al., 2001). These studies prompted the establishment of a permanent tower, which has been used to improve our understanding of how fire affects mass and energy exchange at the ecosystem (Beringer et al., 2003, 2007) and leaf scale (Cernusak et al., 2006) and on soil greenhouse gas exchanges (Livesley et al., 2011). Howard Springs was later used as a key site in the Savanna Patterns of Energy and Carbon Integrated across the Landscape (SPECIAL) campaign, which looked at variations in savanna carbon, water and energy fluxes down the ecological North Australian Tropical Transect (NATT) (Beringer et al., 2011a, b). The composition of standing biomass at the site has also been well documented (O'Grady et al., 2000; Hutley et al., 2011) as has the carbon balance and NEP (Chen et al., 2003; Beringer et al., 2007; Kanniah et al., 2009, 2011). Howard Springs has also been an important Australian site used as observational input for a number of ecosystem modelling studies (Whitley et al., 2011; Ma et al., 2013; Haverd et al., 2013a). These studies have contributed to our understanding of the soil-land-atmosphere interactions that occur within savannas. Now, a further piece of the puzzle is being added with this study, which will contribute insight into the individual dynamics of tree and grass productivity.

The Howard Springs site is described in detail by Hutley et al. (2013), so only a summary is provided here. Longterm (1941-2014) mean annual rainfall for the Darwin Airport is $1732( \pm 44 \mathrm{SE}) \mathrm{mm}$, (Australian Bureau of Meteorology (BoM), station ID: 014015, www.bom.gov.au), which is approximately $20 \mathrm{~km}$ from Howard Springs. The majority of this rainfall (85-95\%) occurs within the rainy season from mid-October to mid-April and little to no rainfall occurs during the dry season months from mid-April to September (Cook and Heerdegen, 2001). This drives a large seasonal contrast in growth, particularly in the understory (Fig. 1). Mean air temperature varies very little from month to month, with a mean daily maximum range of 30.6 to $33.3^{\circ} \mathrm{C}$ and a mean daily minimum range of 19.3 to $25.3^{\circ} \mathrm{C}$
(BoM). Soils are predominantly red Kandosols (Isbell, 1996) that are sandy and loamy, well weathered and nutrient poor. Vegetation is predominantly open forest savanna (Fox et al., 2001; Kanniah et al., 2009), consisting of a woody C3 overstory formed primarily by evergreen Eucalyptus tetrodonta (F. Muell.) and Eucalyptus miniata (Cunn. Ex Schauer), which are common savanna tree species found across northern Australia (Brooker, 2006). The tree canopy extends to a height of $18 \mathrm{~m}$, with a density of 661 stems ha $^{-1}$ (Hutley et al., 2011). Erythrophleum chlorostachys (F. Muell.) and Terminalia ferdinandiana (F. Muell) can also be found amongst the dominant overstory species (Hutley et al., 2000; Beringer et al., 2011a). These species drop between 50 to $100 \%$ of their leaves during the dry season (Williams et al., 1997; O'Grady et al., 2000) thereby adding a semi- to fully deciduous component to the overstory.

The understory is comprised mainly of C4 grasses, the bulk biomass consisting of the annual Sorghum intrans, with a smaller abundance of the perennial Heteropogon triticeous and $S$. plumosum. S. intrans grow $1-3 \mathrm{~m}$ in height, depending on light availability, and consists of a single stem (Lazarides et al., 1991; Spangler, 2003), which sets seed in the last few weeks of March each year and persists as a transient seed bank throughout the dry season (Andrew and Mott, 1983). After seeding, the adult plant senesces and cures to form a highly flammable fuel load (i.e. 158$426 \mathrm{~g}$ dry mass $\mathrm{m}^{-2} \mathrm{yr}^{-1}$ (Beringer et al., 2007), Fig. 1). Also present in the understory are Cycas armstrongii (cycad) and juvenile overstory species. The understory is highly dynamic due to the boom-bust phenology of the $\mathrm{C} 4$ grasses and the competition for resources that exists between these grasses and the other understory species (Fig. 1). Fire is one of the major disturbances in the Howard Springs region, with a recurrence interval of 1-3 years (Russell-Smith and Yates, 2007). Cyclone activity and land use change are other disturbances that are common in the region, but which occur over longer timescales (Hutley et al., 2013).

\subsection{Eddy covariance flux measurements}

The eddy covariance technique was used at Howard Springs to estimate ecosystem and understory fluxes of carbon and water. Fluxes from the savanna ecosystem tower (overstory and understory combined) were taken from the existing longterm tower (instruments at $21 \mathrm{~m}$ ) and were supplemented by an understory tower (instruments at $5 \mathrm{~m}$ ) for a 2-year period from September 2012 to October 2014. The understory tower was located $10 \mathrm{~m}$ to the west of the ecosystem tower. Overstory cover at Howard Springs is approximately $50 \%$ (Kanniah et al., 2009), so the understory tower was located in a representative spot taking this into consideration. However, we did ensure no large trees were too close to the tower (i.e. $<5 \mathrm{~m}$ ), as these can cause wake turbulence and confound the turbulent fluxes. 


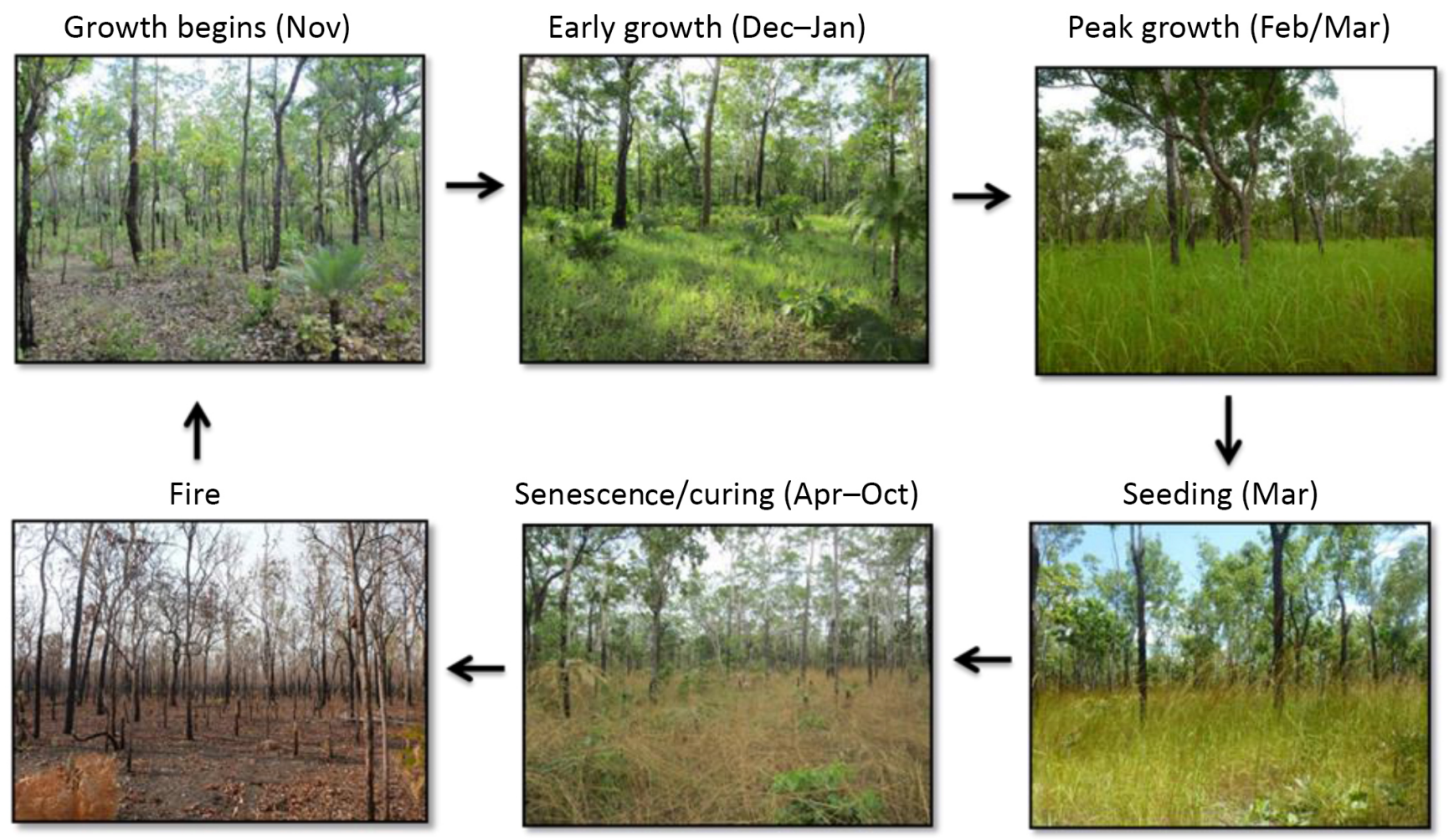

Figure 1. The variability in understory vegetation at Howard Springs OzFlux site, Northern Territory, Australia. The months from late October to early November are when growth in the understory begins, which continues on through the wet season until the end of March and start of April, when the understory grasses senesce and cure. The understory remains dry throughout the dry season months unless fire removes dry biomass.

Flux tower instrumentation is described by Beringer et al. (2003), and Hutley et al. (2005) provides further description of eddy covariance theory and data collection in application to savannas (See Table 1 for a full list of tower instrumentation). In summary, both overstory and understory turbulent exchange measurements were carried out using a 3-D sonic anemometer (CSAT3, Campbell Scientific, Logan, UT) and an open-path infra-red gas analyser (LI-7500, LiCOR Biosciences, Lincoln, NE), which sampled at a rate of $10 \mathrm{~Hz}$ with $30 \mathrm{~min}$ block averaging. The gas analyser was remarkably stable but was still re-calibrated every 6-12 months in the lab using NOAA-CMDL gas standards. Soil heat flux and net radiation were measured as per Beringer et al. (2003) and using this we calculated the available energy and the energy balance closure for the ecosystem tower. This provided us with an important initial indicator of systematic error in our flux estimates. Energy balance closure, using daily averaged data to negate the diurnal effects of storage (Leuning et al., 2012) for the ecosystem tower gave a slope of 0.89 and an $r^{2}$ of 0.92 . We did not attempt to calculate the energy balance closure for the understory tower as it was too difficult to obtain a representative measurement of within-canopy net radiation. Given the average energy balance closure rate for towers across Fluxnet is 0.84 ( $\pm 0.2 \mathrm{SE}$ ) (Stoy et al., 2013), our ecosystem tower has acceptable energy balance closure and thus gives us one measure of confidence in the use of turbulent fluxes at our site.

To assess the extent of the understory flux tower footprint within that of the ecosystem flux tower, we used the approach of Kljun et al. (2004) implemented in EddyPro v4.1.0 (LICOR Biosciences, Lincoln, NE). This analysis revealed that during daytime turbulent conditions, the main tower fetch extended up to $205( \pm 9) \mathrm{m}$, primarily in the west to northwest directions in the wet season and south to southeast directions in the dry season. The understory tower fetch extended to 44 $( \pm 9) \mathrm{m}$, primarily in the west and northwest direction in the wet season and east to southeast direction in the dry season. While these two fetch areas do not completely overlap at all times due to the spatial separation of the towers, vegetation composition at the site is homogenous when viewed at these spatial scales. This gives us confidence that the understory tower is measuring a representative subset of the ecosystem tower.

\subsection{Data quality assurance and analysis}

As we could not determine the energy balance closure for the understory tower, we performed a power spectra and 
Table 1. List of instrumentation installed on the ecosystem and understory flux towers at the Howard Springs OzFlux site; where " $u$ " is the along wind component, " $v$ " is the across wind component and " $w$ " is the vertical wind component of wind velocity in 3-dimensional space, $K \downarrow$ and $L \downarrow$ refer to incoming and $K \uparrow$ and $L \uparrow$ refer to outgoing shortwave and longwave radiation, respectively.

\begin{tabular}{|c|c|c|c|}
\hline Instrument & Make & Model & Description \\
\hline \multicolumn{4}{|l|}{ Main Tower } \\
\hline Open path $\mathrm{CO}_{2}, \mathrm{H}_{2} \mathrm{O}$ & $\mathrm{Li}-\mathrm{COR}$ & LI-7500 & $23 \mathrm{~m}$ \\
\hline Slow response $\mathrm{CO}_{2}$ concentration sensor & Vaisala & GMM220 & $23 \mathrm{~m}$ \\
\hline Sonic Anemometer & Campbell Scientific & CSAT-3 & $23 \mathrm{~m}$ \\
\hline \multicolumn{4}{|l|}{-wind velocities $(u, v, w)$} \\
\hline \multicolumn{4}{|l|}{-sonic temperature } \\
\hline Solar radiation $(K \uparrow, K \downarrow, L \uparrow, L \downarrow)$ & Kipp and Zonen & CNR4 & $23 \mathrm{~m}$ \\
\hline Solar net radiation & Kipp and Zonen & NR-Lite & $23 \mathrm{~m}$ \\
\hline Solar direct/diffuse & DeltaT Devices & SPN1 & $23 \mathrm{~m}$ \\
\hline Atmospheric Pressure & $\mathrm{Li}-\mathrm{COR}$ & LI-7500 & $23 \mathrm{~m}$ \\
\hline Soil heat flux (4 replicates) & REBS & HFT3 & $-8 \mathrm{~cm}$ \\
\hline Soil moisture & Campbell Scientific & CS616 & -10 to $-140 \mathrm{~cm}$ \\
\hline Soil Temperature & Campbell Scientific & TCAV & $-8 \mathrm{~cm}$ \\
\hline Temperature and Relative Humidity & Vaisala & HMP45A & 2 and $23 \mathrm{~m}$ \\
\hline Rain Gauge & Hydrological Services & TB3 & Ground \\
\hline Data Logger & Campbell Scientific & CR-3000 & $1.5 \mathrm{~m}$ \\
\hline Power Supply & Kyocera & Solar panels (6) and battery bank & Ground \\
\hline \multicolumn{4}{|l|}{$-12 \mathrm{~V}$ DC EC flux station } \\
\hline Camera & Vivotek & IP8362 & $23 \mathrm{~m}$ \\
\hline PAR Quantum sensor & $\mathrm{Li}-\mathrm{COR}$ & LI-191 & $2 @ 23 \mathrm{~m}$ \\
\hline 4-channel light sensor & Skye Instruments & SKR-1850 & 2 @ $23 \mathrm{~m}$ \\
\hline \multicolumn{4}{|l|}{ Understory Tower } \\
\hline Open path $\mathrm{CO}_{2}, \mathrm{H}_{2} \mathrm{O}$ & $\mathrm{Li}-\mathrm{COR}$ & LI-7500 & $5 \mathrm{~m}$ \\
\hline Sonic Anemometer & Campbell Scientific & CSAT-3 & $5 \mathrm{~m}$ \\
\hline \multicolumn{4}{|l|}{-wind velocities $(u, v, w)$} \\
\hline -sonic temperature & & & \\
\hline Solar radiation (All-wave) & Kipp and Zonen & NR-Lite & $5 \mathrm{~m}$ \\
\hline Temperature and Relative Humidity & Vaisala & HMP45C & $5 \mathrm{~m}$ \\
\hline Data Logger & Campbell Scientific & CR-3000 & $1.5 \mathrm{~m}$ \\
\hline
\end{tabular}

co-spectra analysis to ensure the understory flux measurement system was consistent with known characteristics of turbulent transport (Kaimal and Finnigan, 1994). Use of the eddy covariance technique for measuring turbulent fluxes requires sufficient sampling frequency and duration to ensure the technique captures the complete spectrum of eddies contributing to turbulent transfer and to avoid aliasing (Baldocchi and Meyers, 1991). We analysed $10 \mathrm{~Hz}$ data using EddyPro v4.1.0 (Li-COR Biosciences, Lincoln, NE). Normalized ensemble averaged data, binned by frequency, $\pm 1 \mathrm{~h}$ of solar noon (12:00-14:00 ACST), were averaged for five consecutive days in the wet season and dry season $(10 \mathrm{~h}$ of data per season) and standard power curves were overlain (Kaimal and Finnigan, 1994).

The importance of standardisation of eddy covariance data processing for inter-annual and inter-site comparison has been encouraged for some time in the flux community ( $\mathrm{Pa}-$ pale et al., 2006). For this reason, our 30 min eddy covariance data were quality assured and quality controlled (QA/QC) using the OzFlux standard processing protocol implemented through the OzFluxQC v2.9.4 python scripts, which were developed under creative common licensing by the OzFlux community and can be freely accessed via the OzFlux website (http://www.ozflux.org.au/). Eamus et al. (2013) provided the first summary of the QA/QC processes and corrections involved in the OzFluxQC protocol. In brief, the OzFlux QA/QC process involves making a range test and removal of data spikes, removal of fluxes where more than $1 \%$ of $10 \mathrm{~Hz}$ observations are missing from the $30 \mathrm{~min}$ average, linear corrections for sensor drift and calibration changes, and rejection of observations when wind originates from behind the 3-D anemometer and tower. A number of corrections are also applied to the data during the QA/QC process, which include frequency attenuation, 2-D coordinate rotation, conversion of sensible heat from virtual to actual flux, application of the WPL correction to account for density effects of heat and water vapour transfer on fluxes (Webb et al., 1980), and correction of soil moisture and soil heat flux measurements. 
Once the OzFluxQC checks and corrections were applied, the percentage of carbon flux (NEE), latent heat flux $\left(F_{\mathrm{e}}\right)$ and sensible heat flux $\left(F_{\mathrm{h}}\right)$ measurements that were either missing or rejected was approximately $11( \pm 1 \mathrm{SE}) \%$ for the understory tower and $20( \pm 1 \mathrm{SE}) \%$ for the ecosystem tower. These gaps were filled using a processing package called DINGO (Dynamic INtegrated Gap filling and partitioning for OzFlux, Beringer, unpublished), also developed in Python. This advanced processing technique scans the OzFlux QA/QC'd data and applies a linear interpolation to gaps of $<2 \mathrm{~h}$. For gaps $>2 \mathrm{~h}$, DINGO searches for the 10 closest Australian Bureau of Meteorology (BoM) monitoring sites from a localised database and creates correlations with the flux data set to find the BoM site with the best correlation and then gap fills using the BoM data. Temperature, humidity, pressure, precipitation and wind speed are all gap filled in this way. Solar radiation is gap filled using gridded satellite radiation and MODIS albedo product (MOD43B3) data. Soil moisture and temperature gaps were filled using the BIOS2 land surface model of the Community Atmosphere Biosphere Land Exchange (CABLE) land surface system (Haverd et al., 2013a, b), which was driven by $5 \mathrm{~km}$ gridded meteorology from the Australian Water Availability Project (AWAP) (Jones et al., 2009). Artificial neural networks (ANN) as described by Beringer et al. (2007) were used to gap fill NEE, $F_{\mathrm{e}}, F_{\mathrm{h}}$ and $F_{\mathrm{g}}$ (soil heat) fluxes.

We also quantified the model and measurement (random only) error components of NEE based on the work of McHugh et al. (2016). In brief, this technique quantifies measurement error based on a normal distribution of uncertainty, where a daily differencing technique of the critical drivers of NEE identifies where NEE values differ due to random error (Hollinger and Richardson, 2005). Model error was also quantified based on a normal distribution of uncertainty, where actual observations are compared to an equivalently sized gap-filled subsample to identify error in the gap-filling technique (Keith et al., 2009). The combined error estimate is calculated as the quadrature sum of measured and modelled error, assuming independence of the two error estimates.

The $u^{*}$ filtering technique has also been shown to introduce uncertainty in NEP (Papale et al., 2006), so to check this, we re-calculated NEP using the upper $\left(u_{\text {upper }}^{*}=0.39\right)$ and lower $\left(u_{\text {lower }}^{*}=0.17\right) 95 \%$ confidence intervals for $u^{*}$ from the Ecosystem tower. Using the same error estimation technique, we added the difference between NEP from $u^{*}-u_{\text {lower }}^{*}$ and $u^{*}-u_{\mathrm{upper}}^{*}$ to the quadrature calculation to account for $u^{*}$ filtering.

\subsection{Partitioning NEE}

Nocturnal NEE is taken to be equal to respiration and measurements of NEE (and hence respiration) are considered reliable when turbulent transport is sufficient, as defined by a threshold friction velocity $\left(u^{*}\right)$ (Goulden et al., 1996). The $u^{*}$ threshold for our site was determined using the DINGO sys- tem that implements the approach of Reichstein et al. (2005). This gave a threshold of $0.07 \mathrm{~m} \mathrm{~s}^{-1}$ for the understory and $0.26 \mathrm{~m} \mathrm{~s}^{-1}$ for the ecosystem. Each half hourly value of NEE is checked and if the observed $u^{*}$ falls below the threshold, DINGO removes the NEE value. All valid night-time NEE values were considered as respiration and an ANN was trained to predict respiration with inputs of soil moisture, soil temperature, air temperature and the normalised difference vegetation index (NDVI). Missing values of respiration were gap filled using the predicted values of respiration from the ANN and the predicted values were then extrapolated to the daytime. This process was performed for both tower data sets, which gave us respiration at the ecosystem (ER), understory (UR) and overstory (OR) scales. We assumed OR to be the difference between ER and UR.

Once respiration was determined, we calculated GPP (as NEE-R). Once a full time series of NEE and GPP and respiration were calculated for both towers, the above-ground overstory OR and GPP were calculated by a simple subtraction of understory values from ecosystem values. This technique assumes that, under sufficient turbulent conditions, fluxes measured by the ecosystem tower in excess of the understory tower are fluxes originating from the above-ground overstory (i.e. primarily tree foliage). The height of the understory tower ensures that fluxes measured by the tower should only originate from the understory vegetation during turbulent conditions, however a small contribution may occur from overstory stems located within the understory flux footprint.

We also assessed seasonal patterns of flux components by defining the wet and dry seasons based on Cook and Heerdegen (2001). These authors define each season based on the probability of the occurrence of a 10-day dry period, which we used to define the "wet" season as the 6 months from 15 October to 15 April (90-95\% of annual rainfall) and the "dry" season as the 6 months from 16 April to 14 October. We adopted the biological method for dealing with fluxes whereby positive values represent a net sink/uptake of carbon by the savanna and negative values represent a net source/release of carbon from the savanna (Chapin III et al., 2006).

\section{Results}

\subsection{Validation of the understory tower}

Results from the power spectra and co-spectra analysis revealed that the understory flux system at Howard Springs was consistent with expected characteristics of turbulent transfer of $\mathrm{CO}_{2}$, water and heat as outlined by Kaimal and Finnigan (1994) (Fig. 2). The wet season showed strong turbulent mixing of all three entities, which is evident from their decay rates in the inertial sub-range mirroring that of the ideal decay rate from Kaimal and Finnigan (1994). In contrast, the 
dry season shows a weaker relationship between turbulence and these components, which is most likely due to the reduced absolute flux magnitudes of $\mathrm{CO}_{2}$ and water, not from instrumental errors. It is common to see "messy" co-spectra during periods of minimal flux or under low-turbulent conditions (Burba, 2013), so our dry season result is not surprising. Tree canopy cover is $50 \%$ at Howard Springs (Kanniah et al., 2009), so reasonable turbulent mixing within the canopy is likely, particularly during the day. As such, confidence can be placed in the understory fluxes given the moderately open tree canopy (Misson et al., 2007). Further, understory systems have been successfully deployed to monitor robust within-canopy fluxes in both open and closed canopy ecosystems (Baldocchi and Meyers, 1991; Blanken et al., 1998; Law et al., 1999; Lamaud et al., 2001; Falk et al., 2005; Launiainen et al., 2005; Ma et al., 2007; Misson et al., 2007).

\subsection{Net ecosystem productivity}

Net ecosystem productivity (NEP) was defined as the daily sum of NEE data. Strong seasonality is evident in ecosystem NEP, which tracks variability in rainfall (Fig. 3). The savanna ecosystem remained a sink of carbon for most of the annual cycle except for late dry season conditions when it approached a carbon neutral state or was a weak source to the atmosphere (Fig. 3). On a seasonal basis, ecosystem NEP has a larger sink in the wet season, with an average of 325.5 ( $\pm 78 \mathrm{SE}$ ) $\mathrm{g} \mathrm{C} \mathrm{m}^{-2}$ season $^{-1}$, compared to a lesser sink in the dry season, with an average of $193.7( \pm 55 \mathrm{SE})$ $\mathrm{g} \mathrm{C} \mathrm{m}^{-2}$ season $^{-1}$ (note: seasons are defined as 6 months each). On an annual basis, NEP of the savanna ecosystem over the 2 years was $506.2( \pm 22 \mathrm{SE}) \mathrm{g} \mathrm{C} \mathrm{m}^{-2} \mathrm{yr}^{-1}$, indicating this mesic savanna was a large net sink of carbon.

In contrast to ecosystem NEP, the understory ( $5 \mathrm{~m}$ tower) system measured a net source of carbon to the atmosphere with an annual average of -722.5 ( $\pm 14 \mathrm{SE}) \mathrm{g} \mathrm{C} \mathrm{m}^{-2} \mathrm{yr}^{-1}$ released (Table 3). This is due to the multiple respiration sources captured by the understory flux system that outweigh the photosynthetic uptake of the understory grasses and shrubs. The understory flux system integrates carbon efflux from root respiration (both trees and grasses), shrub, woody re-sprout and grass foliage and stem respiration, plus heterotrophic respiration that occurs below the measurement height $(5 \mathrm{~m})$ of the system. This large respiration source outweighs the productivity of the understory grasses resulting in the NEP source measured by the understory system.

The NEP figures presented from our research inevitably include a degree of uncertainty due to measurement (random and systematic) and model error. We quantified these errors (Table 4), which revealed that over a given year, combined (random and model) uncertainty in NEP for the ecosystem tower ranged between 27.3 to $36.4 \mathrm{~g} \mathrm{C} \mathrm{m}^{-2} \mathrm{yr}^{-1}$ (5$7 \%$ of total NEP) and between 33.6 to $43.8 \mathrm{~g} \mathrm{C} \mathrm{m}^{-2} \mathrm{yr}^{-1}$ for the understory tower (4-6\% of total NEP). Estimation of the $u^{*}$ error for the ecosystem tower revealed a range
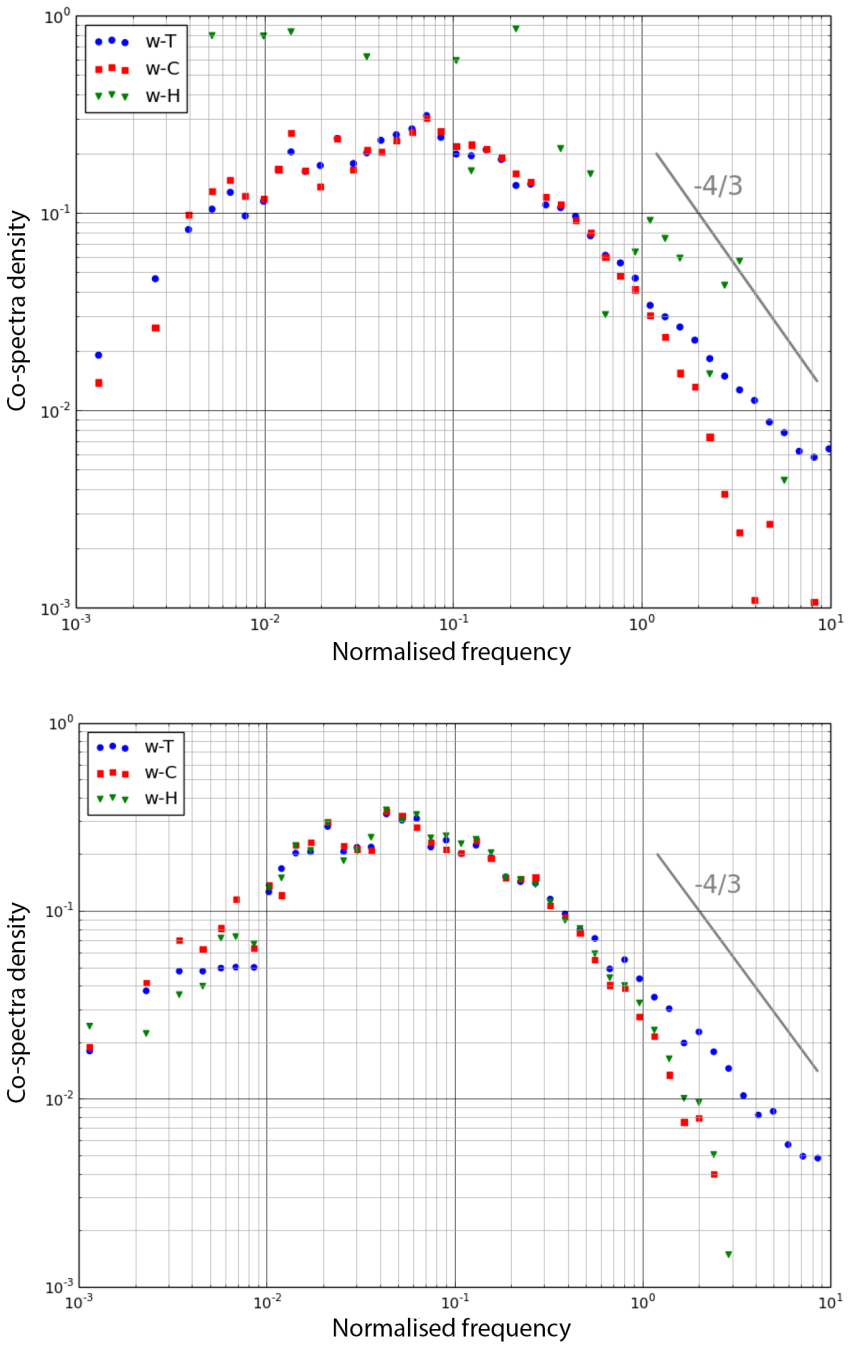

Figure 2. Co-spectra plot of vertical wind $(w)$ against fluxes of carbon $(w-\mathrm{C})$, water $(w-\mathrm{H})$ and energy $(w-T)$ for Howard Springs understory tower for the (a) dry season and (b) wet season. Co-spectra are grouped into 50 exponentially spaced frequency bins and represent times from 1200 to 1400, which are averaged over five consecutive days without rainfall for each season.

Table 2. Records of fire activity at the Howard Springs OzFlux site from years 2012 to 2014 .

\begin{tabular}{llll}
\hline Year & 2012 & 2013 & 2014 \\
\hline Julian day & $\begin{array}{l}\text { Day 231 } \\
\text { (19 Aug) }\end{array}$ & $\begin{array}{l}\text { Day 158 } \\
\text { (7 Jun) }\end{array}$ & $\begin{array}{l}\text { Day 255 } \\
(\text { 12 Sep) }\end{array}$ \\
$\begin{array}{l}\text { Mean intensity } \\
\left(\mathrm{kW} \mathrm{m}^{-1}\right)\end{array}$ & $\sim 2500$ & $\sim 1000$ & $\sim 2200$ \\
\hline
\end{tabular}

of $25.1 \mathrm{~g} \mathrm{C} \mathrm{m}^{-2} \mathrm{yr}^{-1}$ for $u_{\text {lower }}^{*}$ and $44.0 \mathrm{~g} \mathrm{C} \mathrm{m}^{-2} \mathrm{yr}^{-1}$ for $u_{\text {upper }}^{*}$. Papale et al. (2006) found that NEP uncertainties, with $u^{*}$ accounted for, ranged between 15 to $100 \mathrm{~g} \mathrm{C} \mathrm{m}^{-2} \mathrm{yr}^{-1}$ for deciduous and evergreen sites in Europe. Given this range, 
Table 3. Seasonal sums and annual mean $( \pm$ SE) of net ecosystem productivity (NEP), respiration $(R)$ and gross primary productivity $(\mathrm{GPP})$ calculated for the savanna ecosystem, understory and overstory components at the Howard Springs OzFlux site, Northern Territory, Australia. Seasonal measurements are given in $\mathrm{g} \mathrm{C} \mathrm{m}^{-2}$ season ${ }^{-1}$ and annual measurements are given in $\mathrm{g} \mathrm{C} \mathrm{m}^{-2} \mathrm{yr}^{-1}$.

\begin{tabular}{|c|c|c|c|c|c|c|c|c|c|c|}
\hline & & \multicolumn{3}{|c|}{ 2012-2013 sums } & \multicolumn{3}{|c|}{ 2013-2014 sums } & \multicolumn{3}{|l|}{ Mean $( \pm \mathrm{SE})$} \\
\hline & & Wet Season & Dry Season & Annual & Wet Season & Dry Season & Annual & Wet season & Dry season & Annual \\
\hline \multirow[t]{3}{*}{ Ecosystem } & NEP & 389.8 & 138.7 & 528.5 & 235.3 & 248.6 & 483.9 & $325.5( \pm 78)$ & $193.7( \pm 55)$ & $506.2( \pm 22)$ \\
\hline & $R$ & -1153.9 & -664.8 & -1818.7 & -1102.7 & -600.5 & -1703.1 & $-1128.3( \pm 26)$ & $-632.6( \pm 33)$ & $-1760.9( \pm 58)$ \\
\hline & GPP & 1543.6 & 803.5 & 2347.1 & 1337.9 & 849.1 & 2187.0 & $1440.8( \pm 103)$ & $826.3( \pm 23)$ & $2267.1( \pm 80)$ \\
\hline \multirow[t]{3}{*}{ Understory } & NEP & -376.9 & -332.4 & -709.3 & -413.1 & -322.6 & -735.7 & $-395.0( \pm 18)$ & $-327.5( \pm 5)$ & $-722.5( \pm 14)$ \\
\hline & $\mathrm{R}$ & -1004.5 & -456.8 & -1461.3 & -923.9 & -501.2 & -1425.1 & $-964.2( \pm 40)$ & $-479.0( \pm 22)$ & $-1443.2( \pm 18)$ \\
\hline & GPP & 627.6 & 124.4 & 752.0 & 510.8 & 178.6 & 689.4 & $569.2( \pm 59)$ & $151.5( \pm 28)$ & $720.7( \pm 18)$ \\
\hline \multirow[t]{2}{*}{ Overstory } & $R$ & -149.4 & -208.0 & -357.4 & -163.7 & -99.3 & -263.0 & $-156.5( \pm 08)$ & $-153.7( \pm 55)$ & $-317.7( \pm 47)$ \\
\hline & GPP & 916.0 & 679.1 & 1595.1 & 705.3 & 670.5 & 1375.9 & $810.7( \pm 106)$ & $674.8( \pm 5)$ & $1546.4( \pm 110)$ \\
\hline
\end{tabular}

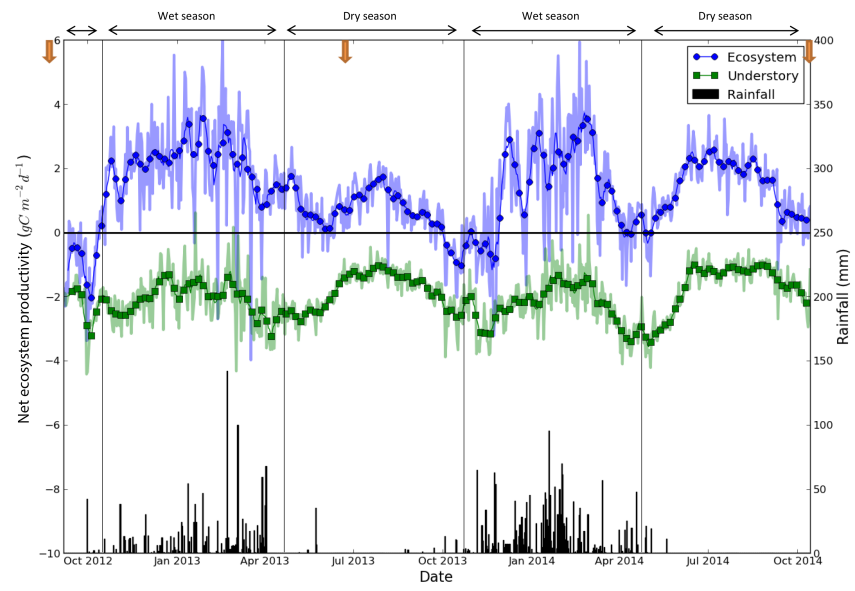

Figure 3. Net Ecosystem Productivity (NEP) for savanna ecosystem ( $23 \mathrm{~m}$ tower) and understory ( $5 \mathrm{~m}$ tower) components at the Howard Springs OzFlux site, Northern Territory, Australia from September 2012 to October 2014. Data shown are daily NEP totals with a 10day running mean to aid visualisation. Orange arrows represent the timing of fire events (for fire intensity see Table 2). Positive fluxes indicate a net sink of carbon to the savanna whereas negative fluxes are a net source of carbon to the atmosphere. Rainfall is also included as daily totals.

we are confident that the $u^{*}$ filter has performed well as a filter for NEP at our site.

\subsection{Partitioning: respiration}

Respiration is a vital component of the carbon balance of ecosystems, being the main process governing the transfer of carbon from an ecosystem back to the atmosphere. Partitioning of the observed NEP into the components of GPP and ER revealed strong seasonality in respiration that closely followed the presence of rainfall (Fig. 4). On an annual basis, savanna ER was $-1760.9( \pm 58 \mathrm{SE}) \mathrm{g} \mathrm{C} \mathrm{m}^{-2} \mathrm{yr}^{-1}$ (Table 3). In comparison, UR was $-1443.2( \pm 18 \mathrm{SE}) \mathrm{g} \mathrm{C} \mathrm{m}^{-2} \mathrm{yr}^{-1}$, indicating that $\sim 82 \%$ of ER is derived from the understory in these savannas (Fig. 4, Table 3). UR dominated the season-

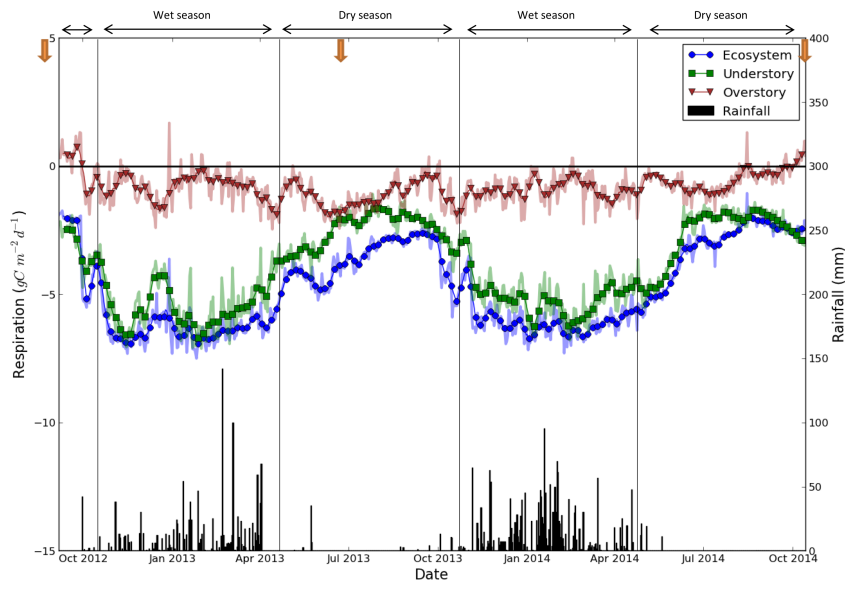

Figure 4. Respiration $(R)$ for savanna ecosystem ( $23 \mathrm{~m}$ tower), understory ( $5 \mathrm{~m}$ tower) and overstory (difference between 23 and $5 \mathrm{~m}$ towers) components at the Howard Springs OzFlux site, Northern Territory, Australia from September 2012 to October 2014. Data shown are daily $R$ totals with a 10-day running mean to aid visualisation. Orange arrows represent the timing of fire events. Positive fluxes indicate a net sink of carbon to the savanna whereas negative fluxes are a net source of carbon to the atmosphere. Rainfall is also included as daily totals.

ality of ER, going from $33 \%$ of annual in the dry season to $67 \%$ of annual in the wet season (Table 3). Compared with UR, OR shows much less seasonality, with the dry season contributing $48 \%$ and the wet season $52 \%$ to the annual sum (Fig. 4, Table 3). In addition, it also contributes only a small portion (18\%) to ER (Fig. 4, Table 3 ).

\subsection{Partitioning: gross primary productivity}

Savanna productivity is strongly influenced by incoming radiation and soil moisture, which are directly linked with precipitation and cloud cover variability in the wet season (Kanniah et al., 2010; Whitley et al., 2011). The wet season is the primary period of productivity in savannas, accounting for $64 \%$ of annual GPP (Fig. 5, Table 3). In contrast, the dry 
Table 4. Error estimates for net ecosystem exchange for the ecosystem and understory flux towers at Howard Springs OzFlux site, Northern Territory, Australia. Estimates are given for each year (2012-2014) and are presented as day (D), night (N) and total (T) error estimates in $\mathrm{g} \mathrm{C} \mathrm{m}^{-2} \mathrm{t}^{-1}$, where $t$ is day, night or year.

\begin{tabular}{lllllrrrrr}
\hline & & \multicolumn{3}{c}{$\begin{array}{c}\text { Available \& Percentage } \\
(n, \%) \text { observations }\end{array}$} & \multicolumn{2}{c}{$\begin{array}{c}\text { Model } \\
\text { error }\end{array}$} & $\begin{array}{c}\text { Random } \\
\text { error }\end{array}$ & $\begin{array}{r}\text { Combined } \\
\text { error }\end{array}$ \\
\cline { 2 - 10 } & Year & $\mathrm{D}$ & $\mathrm{N}$ & $\mathrm{T}$ & $\mathrm{D}$ & $\mathrm{N}$ & $\mathrm{D}$ & $\mathrm{N}$ & $\mathrm{T}$ \\
\hline Ecosystem & 2012 & $2524,87.2$ & $404,14.7$ & 2928,52 & 6.1 & 9.4 & 7.7 & 5.6 & 14.7 \\
& 2013 & $7657,87.9$ & $1653,18.8$ & $9310,53.1$ & 17.1 & 14.3 & 12.9 & 8.9 & 27.3 \\
& 2014 & $6121,90.2$ & $868,12.4$ & $6989,50.7$ & 12.0 & 11.7 & 11.6 & 7.5 & 21.7 \\
Understory & 2012 & 1786,94 & $428,23.2$ & $2214,59.2$ & 1.4 & 7.7 & 4.0 & 5.9 & 10.6 \\
& 2013 & $7744,91.9$ & $2541,28.2$ & 10285,59 & 8.4 & 29.7 & 8.4 & 10.5 & 33.6 \\
& 2014 & $6067,92.7$ & $2025,28.2$ & $8092,58.9$ & 4.4 & 30.8 & 7.4 & 9.0 & 33.2 \\
\hline
\end{tabular}

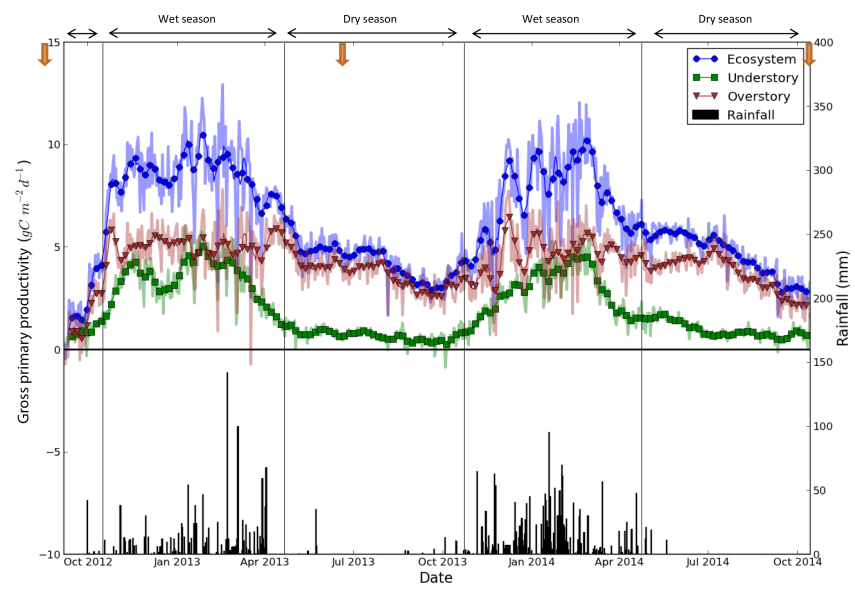

Figure 5. Gross Primary Productivity (GPP) for savanna ecosystem ( $23 \mathrm{~m}$ tower), understory ( $5 \mathrm{~m}$ tower) and overstory (difference between 23 and $5 \mathrm{~m}$ towers) components at the Howard Springs OzFlux site, Northern Territory, Australia from September 2012 to October 2014. Data shown are daily GPP totals with a 10-day running mean to aid visualisation. Orange arrows represent the timing of fire events. Positive fluxes indicate a net sink of carbon to the savanna whereas negative fluxes are a net source of carbon to the atmosphere. Rainfall is also included as daily totals.

season contributes only $36 \%$ to annual GPP (Fig. 5, Table 3). This is primarily due to the rapid growth of annual $\mathrm{C} 4$ grasses in the understory, which display boom-bust seasonal dynamics. For the duration of this study, the understory contributed $32 \%$ to the total ecosystem uptake via GPP (Fig. 5, Table 3). Of this annual understory GPP contribution, $79 \%$ occurred in the wet season and only $21 \%$ in the dry season.

Relative to the understory, seasonal variability of overstory GPP was low and varied from $44 \%$ (dry season) to $53 \%$ (wet season) of annual GPP despite the major shift in surface soil moisture content from the wet to dry season (Fig. 5, Table 3). Large temporal dynamics in overstory GPP were driven not by climate but by fire events (Beringer et al., 2007), where overstory GPP fell close to zero following moderate intensity fire (i.e. September 2012, Table 2), then recovered once overstory reconstruction occurred (i.e. December 2012; Fig. 5). Annual GPP at Howard Springs during this study was 2267.1 ( $\pm 80 \mathrm{SE}) \mathrm{g} \mathrm{C} \mathrm{m}^{-2} \mathrm{yr}^{-1}$, which varied from $1440.8( \pm 103 \mathrm{SE}) \mathrm{g} \mathrm{C} \mathrm{m}^{-2}$ season $^{-1}$ in the wet $(64 \%$ of annual) to $826.3( \pm 23 \mathrm{SE}) \mathrm{g} \mathrm{C} \mathrm{m}^{-2}$ season $^{-1}$ in the dry (36\% of annual).

\subsection{Inter-annual variability in savanna fluxes}

Although we are only presenting 2 years of data, these 2 years experienced contrasting meteorology. In terms of interannual variability, the 2012-2013 wet season had considerably higher NEP than the 2013-2014 wet season (389.8 compared to $235.3 \mathrm{~g} \mathrm{C} \mathrm{m}^{-2}$ season $^{-1}$, respectively; Fig. 6, Table 3 ). We defined our wet and dry seasons as per Cook and Heerdegen (2001), which meant our "wet" and "dry" seasons lasted for 6 months each. In 2012-2013, annual rainfall recorded at Howard Springs was $1288 \mathrm{~mm}$, whereas in 2013-2014 it was $1948 \mathrm{~mm}$. Counterintuitively, the corresponding wet season with the lower rainfall total (20122013) had a higher GPP of $1543.6 \mathrm{~g} \mathrm{C} \mathrm{m}^{-2}$ season $^{-1}$ compared with only $1337.9 \mathrm{~g} \mathrm{C} \mathrm{m}^{-2}$ season $^{-1}$ in 2013-2014 (Table 3). During this lower rainfall year, solar radiation was greater and resulted in enhanced growing conditions compared to the 2013-2014 wet season (Fig. 7). This suggests that during the wet season, these savannas can experience light limitation to productivity.

For the dry seasons, the year with the preceding drier wet season (2012-2013) had a lower net sink of 138.7 compared to $248.6 \mathrm{~g} \mathrm{C} \mathrm{m}^{-2}$ season $^{-1}$ (Fig. 6, Table 3). As annual rainfall was higher for 2013-2014, deep soil moisture storage was also higher for longer in the dry season of 2013-2014 than that for 2012-2013 (Fig. 7). The rate of decrease after the last significant rainfall event of the wet season (i.e. April) also supports this, with the year 2013-2014 equating to a loss rate of $0.6 \%$ per week of soil capacity versus $1.3 \%$ per week for the drier 2012-2013 (Fig. 7). The higher rainfall in 20132014 extended the growing season as a result of maintained 

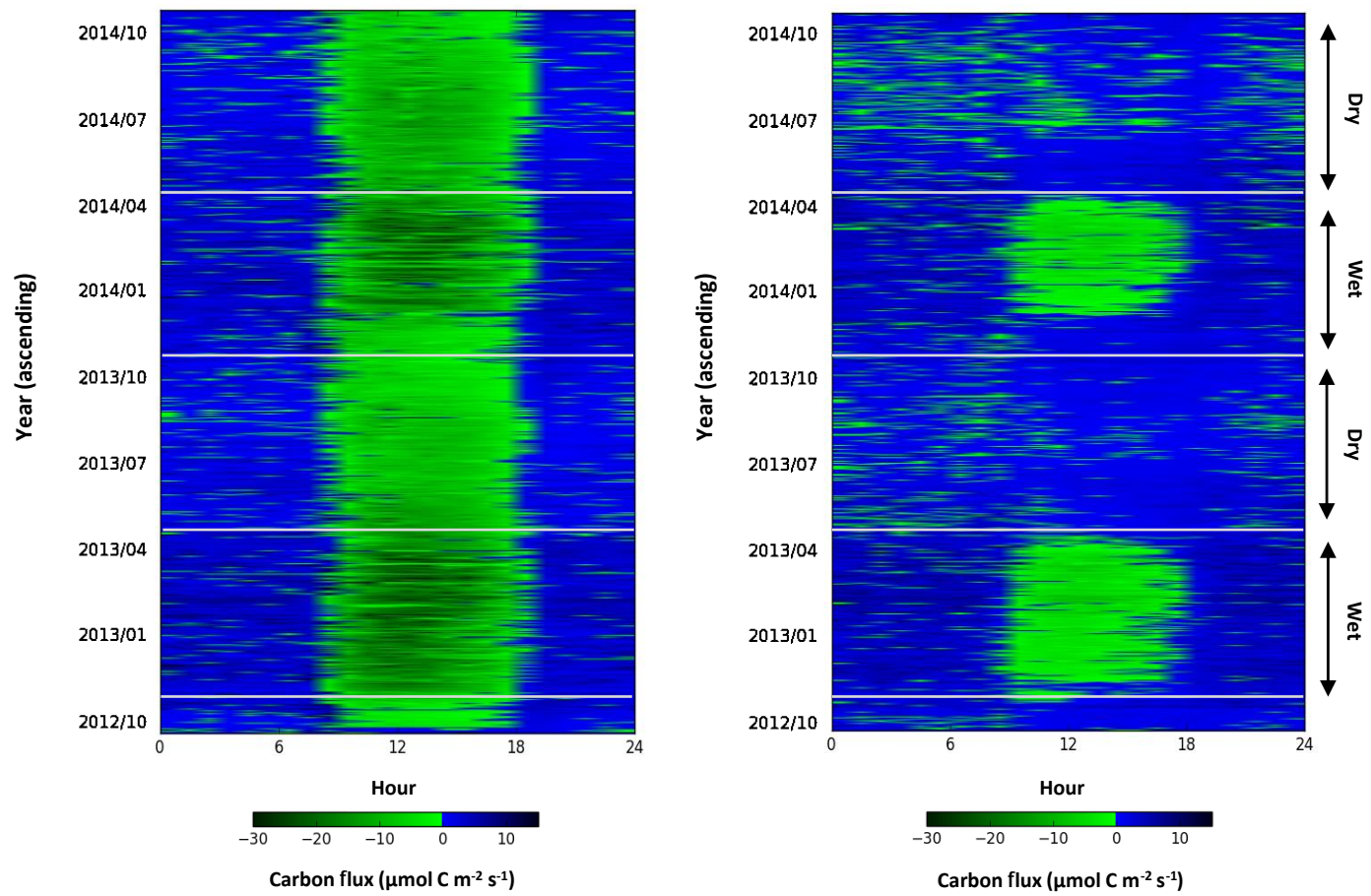

Figure 6. Diurnal ( $x$ axis) fingerprint plot of NEE from the savanna (a) ecosystem ( $23 \mathrm{~m}$ tower) and (b) understory ( $5 \mathrm{~m}$ tower). Measurements shown are for "wet" and "dry" seasons from September 2012 to October 2014 ( $y$ axis) at the Howard Springs OzFlux site, Northern Territory, Australia. Negative NEE represents the uptake of carbon by the savanna, whereas positive NEE represents the loss of carbon from the savanna.

soil moisture at saturation levels for the beginning of the dry season.

\section{Discussion}

\subsection{Net ecosystem productivity}

The NEP result found in this study (506.2 ( \pm 22 SE) $\mathrm{g} \mathrm{C} \mathrm{m}^{-2} \mathrm{yr}^{-1}$ ) is slightly higher than previous carbon balance studies at Howard Springs. Beringer et al. (2007) reported a range of 360 to $430 \mathrm{~g} \mathrm{C} \mathrm{m}^{-2} \mathrm{yr}^{-1}$ using eddy covariance and Chen et al. (2003) used an inventory and allometric approach to derive a value of $380 \mathrm{~g} \mathrm{C} \mathrm{m}^{-2} \mathrm{yr}^{-1}$. A possible reason for these differences is that the Howard Springs savanna was impacted by cyclone Tracy in the 1970s and is still recovering from the effects, which over time would see an increase in NEP (Hutley et al., 2013).

The seasonality in NEP of these savannas appears to be dependent on the productivity of both the seasonally dynamic C4 understory and the steady input from the shrub and $\mathrm{C} 3$ tree overstory. However, due to regularly recurrent fire in these savannas, that consumes understory biomass, the understory grasses contribute minimally to the longer term productivity of these savannas (Hutley and Beringer, 2010; Beringer et al., 2015). Therefore, the increase seen in NEP from the likes of Beringer et al. (2007) and Chen et al. (2003)

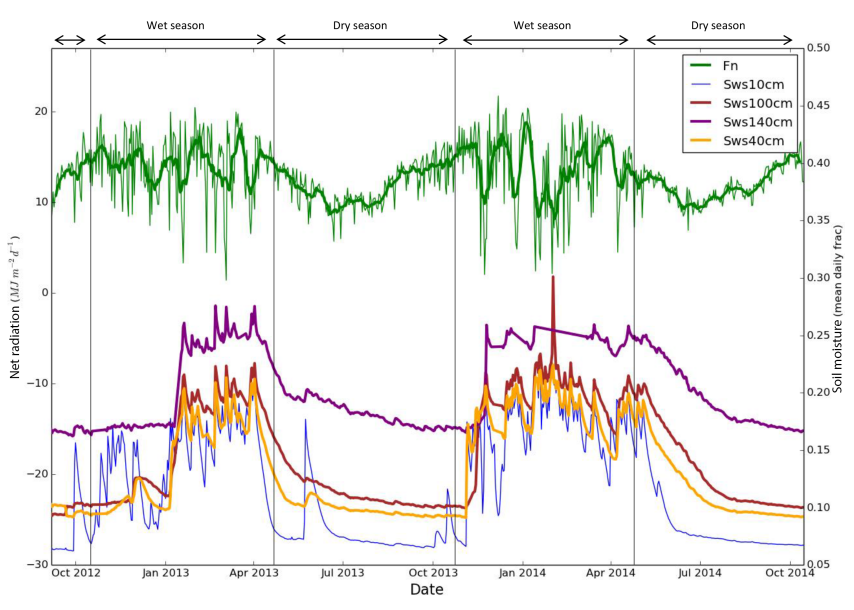

Figure 7. Daily variability in radiation $\left(F_{\mathrm{n}}\right)$ and soil moisture (Sws) at the Howard Springs tropical savanna site, Northern Territory, Australia from September 2012 to October 2014. Mean daily $F_{\mathrm{n}}$ is shown with a 10-day running mean (green) to aid in visualisation and daily mean variability in Sws fraction are shown for $10 \mathrm{~cm}$ (blue), $40 \mathrm{~cm}$ (orange), $100 \mathrm{~cm}$ (brown) and $140 \mathrm{~cm}$ (purple) depths.

to our study is mostly due to the growth of the woody overstory.

The NEP range from Beringer et al. (2007) is also fire dependent and highlights the importance of fire as a major driver of productivity in these savannas. At our site, 1- 
2 weeks before the commencement of this study (August 2012), a moderate-intensity wildfire (Table 2) went through the site and resulted in near-complete removal of understory vegetation and large overstory scorch (Fig. 1). The savanna ecosystem became a net source of carbon for a number of weeks following the fire before returning to a sink around the onset of the wet season (Fig. 3). The work of Beringer et al. (2007) supports this concept, as they found that the cost of re-establishing lost overstory foliage after a fire event in savanna ecosystems resulted in a shift in savannas from a sink to a source of carbon whilst the overstory was rebuilt. New foliage is not immediately photosynthetically active, so the overstory consumes carbon resources to rebuild its canopy with no assimilation to replace it (Cernusak et al., 2006), hence the shift from sink to source.

\subsection{Respiration}

One of the most striking results from our partitioning analysis was the domination of respiration in the understory, which rendered the NEP of the understory as an annual source of carbon to the atmosphere (Fig. 3). The UR value (1443.2 ( $\pm 18 \mathrm{SE}$ ) $\mathrm{g} \mathrm{C} \mathrm{m}^{-2} \mathrm{yr}^{-1}$ ) we estimated from the understory tower was a mixed signal of SR and above-ground understory respiration (AUR), comprising grasses and woody stems below the height $(5 \mathrm{~m})$ of the flux instruments. Chen et al. (2002) monitored SR at Howard Springs using chambers and reported an annual SR rate of $1430 \mathrm{~g} \mathrm{C} \mathrm{m}^{-2} \mathrm{yr}^{-1}$. Another study conducted at Howard Springs using soil chambers estimated annual SR as $1211 \mathrm{~g} \mathrm{C} \mathrm{m}^{-2} \mathrm{yr}^{-1}$ for unburnt plots and $1442 \mathrm{~g} \mathrm{C} \mathrm{m}^{-2} \mathrm{yr}^{-1}$ for burnt plots (Livesley et al., 2011). Likewise, Richards et al. (2012) reported values of SR in a similar savanna ( $\sim 40 \mathrm{~km}$ from Howard Springs) to range between 770 and $1780 \mathrm{~g} \mathrm{C} \mathrm{m}^{-2} \mathrm{yr}^{-1}$ for burnt and unburnt plots, respectively. These figures suggest that our estimate of UR from the partitioned flux data is a reasonable estimate.

To further support our UR results, Chen et al. (2002) reported the wet and dry season components to the annual SR, finding that $71 \%$ of SR occurred in the wet and only $29 \%$ occurred in the dry. These portions are of similar magnitude to those of our study, where the wet season contributed $67 \%$ to annual UR and the dry season $33 \%$. In our study, UR was at its peak in the wet season, where soil moisture was at its highest, and then fell away to its lowest rate in the late dry season (September-October), where soil moisture was at its lowest. In these savannas, soil moisture is the primary driver of SR with soil temperature being a secondary factor only when volumetric soil moisture is above $5 \%$ (Chen et al., 2003; Richards et al., 2012). This trend was most evident at the beginning of the wet season where rainfall would moisten previously dry surface soil layers, thereby initiating soil mineralisation processes, root growth and displacement of $\mathrm{CO}_{2}$ from soil pore spaces (the Birch effect, Birch, 1958). Heterotrophic respiration (HR) is also elevated under moist soil conditions, with the wet season over double the rate of the dry season (i.e. 210 vs. $510 \mathrm{~g} \mathrm{C} \mathrm{m}^{-2}$ season $^{-1}$, Chen et al., 2003).

In contrast to UR, OR did not vary as much over the course of the study period and remained only a small fraction of ER over time (Fig. 4). We would not expect our OR estimate to be large given that OR is only the contribution of tree leaves and stems to ER and that SR makes up the bulk of ER. This is supported by the work of Chen et al. (2003), who estimated OR at Howard Springs to produce $270 \mathrm{~g} \mathrm{C} \mathrm{m}^{-2} \mathrm{yr}^{-1}$. Likewise, Cernusak et al. (2006) estimated an annual OR contribution of $275 \mathrm{~g} \mathrm{C} \mathrm{m}^{-2} \mathrm{yr}^{-1}$, which was calculated by summing stem and leaf respiration measured in situ at the Howard Springs site. These two independent studies both estimated OR within remarkably close range $(\sim 15 \%)$ of our tower-derived estimate of $317.7( \pm 47 \mathrm{SE}) \mathrm{g} \mathrm{C} \mathrm{m}^{-2} \mathrm{yr}^{-1}$, giving us confidence in our OR estimate, despite the large uncertainties of error from both systems.

Whilst the partitioning approach we used provides us with fundamental understanding of how NEE is divided into respiration and GPP, it is important to note that these estimates are subject to inherent uncertainties due to methodological and physical mechanisms. The application of the $u^{*}$ filtering technique can introduce error primarily during the night, when a loss of $\mathrm{CO}_{2}$ resulting from low turbulence and drainage flows can lead to underestimation of night time measured NEE, thus respiration (Aubinet, 2008; van Gorsel et al., 2009; Cleverly et al., 2013). An earlier study that used flux partitioning to estimate savanna respiration and GPP reported annual ER rates of $970 \mathrm{~g} \mathrm{C} \mathrm{m}^{-2} \mathrm{yr}^{-1}$ (Beringer et al., 2007), considerably lower than this study. The two studies are difficult to compare directly due to differences in processing and gap filling techniques for NEE used in each study. The $u^{*}$ threshold value used in the earlier study $\left(0.15 \mathrm{~m} \mathrm{~s}^{-1}\right)$ was determined visually and was fixed at a lower value, causing respiration and GPP to be lower too. The current technique described in this paper for the $u^{*}$ determination is more conservative and results in high respiration and higher GPP (Reichstein et al., 2005). In addition, a considerable archive of data allows for more robust gap filling of data, plus the data periods between the two studies are almost 10 years apart.

Since the $u^{*}$ threshold technique has its obvious drawbacks, soil chamber measurements of SR, given its fraction of respiration, can provide an independent measurement to verify tower derived respiration. However, chambers incur their own limitations through interference with the objects they measure and encounter issues in up-scaling leading to over- or under-estimation of the true respiration flux (Pumpanen et al., 2004; Keith et al., 2009). Although we did not explicitly use soil chambers alongside the flux towers during this study, the extensive monitoring of SR at Howard Springs (Chen et al., 2002; Livesley et al., 2011) has allowed us to compare our results against independent estimates of SR, which compare well with our values. Given that our tower estimates of respiration obtained from partitioned NEE are con- 
sistent within the ranges already published for soil (i.e. Chen et al., 2003; Livesley et al., 2011; Richards et al., 2012) and overstory (i.e. Chen et al., 2003; Cernusak et al., 2006) respiration, we are confident that our processing methods have performed well in partitioning NEE into respiration and GPP.

\subsection{Gross primary productivity}

GPP was highly seasonal at Howard Springs, which was largely driven by the difference in understory productivity from wet to dry season (Fig. 6). This is mostly due to the dominating presence of $\mathrm{C} 4$ grasses in the understory that are primarily active in the wet season (Andrew and Mott, 1983; Whitley et al., 2011). Despite this, understory GPP did not fully cease in the dry season. This small dry season contribution to GPP was most likely that of woody re-sprouts and juvenile overstory species, predominantly eucalypts, taking advantage of the senescent grasses to gain biomass in the early dry season (i.e. May-June, Fig. 1) (Prior et al., 2006; Werner, 2012). At the end of the wet season, data from a biomass harvest indicate that these understory woody species make up $23 \%$ of total understory biomass.

At Howard Springs, an unusually high density of understory cycads (Cycas armstrongii) also flush throughout the dry season, mostly in response to fire or small rainfall events during the early wet season (Watkinson and Powell, 1997). These would also contribute to the observed dry season understory GPP. However, this dry season GPP is small and can be reduced to zero immediately following fire, as was the case at our site in 2013 (Fig. 5). Frequent fires target understory species by consuming fine fuel grassy biomass and suppressing juvenile species. As a consequence, the carbon sequestration potential of these savanna ecosystems is limited, with the removal of 19 to $51 \mathrm{~g} \mathrm{C} \mathrm{m}^{-2} \mathrm{yr}^{-1}$ from the ecosystem every year (Beringer et al., 2007; Murphy et al., 2010).

Overstory GPP was less variable over the course of the study than understory GPP and was affected by fire on a number of occasions (Fig. 5, Table 3). Past work at Howard Springs has shown that when the overstory is not fire affected, it has a modest inter-annual variability (i.e. $\sim 16 \%$ ) in GPP (Beringer et al., 2007), with dry season NEP and evapotranspiration maintained by available moisture sourced from deep soil layers (Cook et al., 1998; O'Grady et al., 1999; Eamus et al., 2002; Kelley et al., 2007). Kelley et al. (2007) used a soil moisture balance technique and sap flow data to infer soil moisture extraction by the overstory down to $4.7 \mathrm{~m}$ at Howard Springs.

Despite the availability of deep soil moisture, there is a slight linear decrease (Fig. 5) evident in overstory GPP from the onset of the dry season to the end that can be attributed to reduced tree leaf area index (LAI). Coinciding with a decrease in LAI is a reduction in leaf stomatal conductance and assimilation rate throughout the dry season as a result of increased atmospheric vapour pressure deficit and soil drying
(Duff et al., 1997; Prior et al., 1997), despite overstory transpiration rates remaining relatively unchanged (O'Grady et al., 1999). Although the Howard Springs site is dominated by evergreen eucalypts, these species are known to have fluctuating LAI (1.01 to 0.75 ) in response to soil drying (Williams et al., 1997; O'Grady et al., 2000). Given that a small portion (i.e. $15 \%$, Hutley et al., 2011) of the overstory are also semi-, brevi- and fully-deciduous species that drop between $50-100 \%$ of their foliage during the dry season (Williams et al., 1997), the observed seasonal variability in GPP is likely a result of the loss of this photosynthetic leaf area (Eamus et al., 2001).

In addition to the loss of leaf area, stem growth slows and then ceases by the late dry season. Therefore, GPP occurring during this period is likely to be allocated to woody tissue maintenance rather than biomass accumulation (Prior et al., 2004; Cernusak et al., 2006). Allocation of carbon for starch reserves, to replace damaged foliage after regular dry season fires, also directs photosynthate away from stem growth (Cernusak et al., 2006; Beringer et al., 2007). The dominant eucalypt species also flower and fruit in the dry season, producing a large number of woody capsules (Setterfield and Williams, 1996), which would redirect carbon allocation from biomass accumulation.

At the ecosystem scale, our estimate of annual GPP (2267.1 ( $\pm 80 \mathrm{SE}) \mathrm{g} \mathrm{C} \mathrm{m}^{-2} \mathrm{yr}^{-1}$ ) was larger when compared to the results of Beringer et al. (2007). This is to be expected from our previous discussion in Sect. 4.2 of the differences between the two derived GPP and respiration estimates. Our result is also larger than that published by two other studies from Howard Springs that reported annual GPP rates of $1365 \mathrm{~g} \mathrm{C} \mathrm{m}^{-2} \mathrm{yr}^{-1}$ (Kanniah et al., 2011) and $1475 \mathrm{~g} \mathrm{C} \mathrm{m}^{-2} \mathrm{yr}^{-1}$ (Whitley et al., 2011). However, these two studies both used the same partitioned data from Beringer et al. (2007). Chen et al. (2003) provide an independent estimate of GPP at the Howard Springs site using an inventory approach based on above- and below-ground measurements of biomass, and calculated annual GPP as $2080 \mathrm{~g} \mathrm{C} \mathrm{m}^{-2} \mathrm{yr}^{-1}$, which is within $8 \%$ of our estimate of GPP. Howard Springs, being relatively close to the coast, was affected by cyclone Tracy in the 1970s and is believed to be still recovering from the impact (Hutley et al., 2013), so we would therefore expect this regrowing site to be a carbon sink. Further research looking back in time at the 15-year flux record for Howard Springs would provide insight into this question, but is beyond the scope of the present study.

\subsection{Inter-annual variability in savanna fluxes}

Our comparison of the two meteorologically contrasting years at Howard Springs implies that GPP in these savannas is light limited. Whitley et al. (2011), investigating limitations on savanna productivity at annual timescales, drew a similar conclusion. They used the Soil-Plant-Atmosphere (SPA) model (Williams et al., 1996) to investigate the phys- 
iological mechanisms responsible for observed carbon and water flux and found that LAI, rather than soil moisture content, was the major driver of savanna GPP. This led Whitley et al. (2011) to conclude that productivity of the mesic savannas in northern Australia is light limited, a conclusion that our wet season data also support.

In contrast to light limitation of the wet season, our data suggest that dry season GPP is more reliant on the amount of rainfall during the preceding wet season (Fig. 6, Table 2). A wetter wet season provides a greater recharge of soil moisture stores (Fig. 7), which would benefit the overstory, as it relies upon deep soil moisture stores to survive the rainless dry season (Eamus et al., 2002; Kelley et al., 2007). Although transpiration rates do not fluctuate significantly from wet to dry season (O'Grady et al., 1999; Hutley et al., 2000), by the late dry season tree productivity is reduced to the point where productivity is used only for maintenance, not growth (Prior et al., 2004). A wetter wet season, resulting in higher soil moisture for longer at deeper layers, would prolong the growing season for the overstory. Myers et al. (1998) found that dry season irrigation resulted in prolonged leaf retention in the early dry season, but by the late dry season, irrigation made no difference to overstory fullness. By the late dry season, soil moisture is at its lowest (Fig. 7). As an adaptation to survive this, the overstory as a whole is also at its lowest canopy cover at this time (Williams et al., 1997; O'Grady et al., 2000).

During the dry season, the understory does remain productive (in terms of GPP), which is not due to grass productivity, as these annual species have already senesced. This smaller sink in the understory results from cycads (Watkinson and Powell, 1997) and juvenile overstory species, whose life histories and productivity are tightly linked to fire (as per NEP section) (Murphy et al., 2010; Werner and Franklin, 2010; Werner, 2012). Given that fire frequency in these savannas is every 1-3 years (Russell-Smith and Yates, 2007), it cannot be ignored when considering the temporal dynamics of savanna productivity. Therefore, we argue that whilst light limitation appears to be the primary driver of productivity in the wet season, the inter-annual productivity of these savannas in the dry season appears to be limited by a more complex interaction of water availability for the overstory, particularly in the early dry season, phenology responses of both the understory and overstory to reduced water availability and variability in the occurrence and intensity of fire.

\section{Conclusion}

We have described the importance of the complex tree-grass relationship for regulating the dynamics of the carbon balance of a tropical savanna in northern Australia. The understory dominated the wet season GPP component as the rapid growth of the $\mathrm{C} 4$ grasses swiftly converts atmospheric carbon into biomass. However, due to the sudden senescence of these $\mathrm{C} 4$ grasses at the onset of the dry season, the understory contributes less than the overstory to annual ecosystem GPP. The strength and duration of the wet season monsoon also played a key role in the productivity of these savannas, with the drier year leading to higher understory productivity, and wetter year providing higher soil moisture stores to support overstory productivity for longer during the dry season. This has important implications for the carbon balance of these savannas in light of future climate change, where altered monsoon regimes are likely to vary annual rainfall totals. Since understory productivity transfers directly into biomass that makes up the dominant fire fuel load in these savannas, if the monsoon becomes weaker it could result in years of greater fire intensity due to the higher fuel load in the understory. This in turn could result in a loss of carbon sequestration and reduced biodiversity in savannas (Scheiter et al., 2015). If the monsoon is to strengthen, the overstory will likely be at a productive advantage over the grasses, which in turn could lead to woody encroachment and a shift in biodiversity (Scheiter et al., 2015). Our research has shown that flux towers can be successfully administered in savanna ecosystems to provide a robust observation-based account of tree and grass productivity dynamics, which can provide useful insights into how these dynamics change over different spatial and temporal scales.

Author contributions. Field work and experimental design was carried out by Caitlin E. Moore, Jason Beringer, Lindsay B. Hutley and Bradley Evans. Data analysis was primarily carried out by Caitlin E. Moore, with supplementary analysis from Jason Beringer (DINGO) and Ian McHugh (error estimation). The manuscript was prepared by Caitlin E. Moore with contributions from all coauthors.

Acknowledgements. First and foremost, the authors would like to acknowledge support and funding from OzFlux and the overarching Terrestrial Ecosystem Research Network (TERN), which is supported by the Australian Government through the National Collaborative Research Infrastructure Strategy. J. Beringer is funded under an Australian Research Council Future Fellowship (FT1110602). B. Evans is funded by the TERN Ecosystem Modelling and Scaling Infrastructure. A special thanks is also made to Dr Peter Isaac for his development of the OzFluxQC standardised processing tools.

Edited by: N. Kljun

\section{References}

Allen, G., Vaughan, G., Bower, K. N., Williams, P. I., Crosier, J., Flynn, M., Connolly, P., Hamilton, J. F., Lee, J. D., Saxton, J. E., Watson, N. M., Gallagher, M., Coe, H., Allan, J., Choularton, T. W., and Lewis, A. C.: Aerosol and trace-gas measurements in 
the Darwin area during the wet season, J. Geophys. Res.-Atmos., 113, D23303, doi:10.1029/2008JD011284, 2008.

Andrew, M. H. and Mott, J. J.: Annuals with transient seed banks: the population biology of indigenous Sorghum species of tropical north-west Australia, Aust. J. Ecol., 8, 265-276, 1983.

Aubinet, M.: Eddy covariance $\mathrm{CO}_{2}$ flux measurements in nocturnal conditions: An analysis of the problem, Ecol. Appl., 18, 13681378, 2008.

Baldocchi, D. D. and Meyers, T. P.: Trace gas exchange above the floor of a deciduous forest 1 . Evaporation and $\mathrm{CO}_{2}$ efflux, J. Geophys. Res., 96, 7271-7285, 1991.

Beer, C., Reichstein, M., Tomelleri, E., Ciais, P., Jung, M., Carvalhais, N., Rödenbeck, C., Arain, M. A., Baldocchi, D., Bonan, G. B., Bondeau, A., Cescatti, A., Lasslop, G., Lindroth, A., Lomas, M., Luyssaert, S., Margolis, H., Oleson, K. W., Roupsard, O., Veenendaal, E., Viovy, N., Williams, C., Woodward, F. I., and Papale, D.: Terrestrial gross carbon dioxide uptake: Global distribution and covariation with climate, Science, 329, 834-838, 2010.

Beringer, J., Hutley, L. B., Tapper, N. J., Coutts, A., Kerley, A., and O'Grady, A. P.: Fire impacts on surface heat, moisture and carbon fluxes from a tropical savanna in northern Australia, Int. J. Wildland Fire, 12, 333-340, 2003.

Beringer, J., Hutley, L. B., Tapper, N. J., and Cernusak, L. A.: Savanna fires and their impact on net ecosystem productivity in North Australia, Glob. Change Biol., 13, 990-1004, 2007.

Beringer, J., Hacker, J., Hutley, L. B., Leuning, R., Arndt, S. K., Amiri, R., Bannehr, L., Cernusak, L. A., Grover, S., Hensley, C., Hocking, D., Isaac, P., Jamali, H., Kanniah, K., Livesley, S., Neininger, B., Paw U, K. T., Sea, W., Straten, D., Tapper, N., Weinmann, R., Wood, S., and Zegelin, S.: Special - Savanna patterns of energy and carbon integrated across the landscape, B. Am. Meteorol. Soc., 92, 1467-1485, 2011 a.

Beringer, J., Hutley, L. B., Hacker, J. M., Neininger, B., and Paw U, K. T.: Patterns and processes of carbon, water and energy cycles across northern Australian landscapes: From point to region, Agr. Forest Meteorol., 151, 1409-1416, 2011 b.

Beringer, J., Hutley, L. B., Abramson, D., Arndt, S. K., Briggs, P., Bristow, M., Canadell, J. G., Cernusak, L. A., Eamus, D., Edwards, A. C., Evans, B. J., Fest, B., Goergen, K., Grover, S. P., Hacker, J., Haverd, V., Kanniah, K., Livesley, S. J., Lynch, A., Maier, S., Moore, C., Raupach, M., Russell-Smith, J., Scheiter, S., Tapper, N. J., and Uotila, P.: Fire in Australian savannas: From leaf to landscape, Glob. Change Biol., 21, 62-81, 2015.

Birch, H. F.: The effect of soil drying on humus decomposition and nitrogen availability, Plant Soil, 10, 9-31, 1958.

Blanken, P. D., Black, T. A., Neumann, H. H., Den Hartog, G., Yang, P. C., Nesic, Z., Staebler, R., Chen, W., and Novak, M. D.: Turbulent flux measurements above and below the overstory of a boreal aspen forest, Bound.-Lay. Meteorol., 89, 109-140, 1998.

Bond, W. J.: What limits trees in $\mathrm{C} 4$ grasslands and savannas?, Annu. Rev. Ecol. Evol. Syst., 39, 641-659, 2008.

Brooker, I.: EUCLID: Eucalypts of Australia, 3rd Edn., CSIRO Publishing, Collingwood, Victoria, 2006.

Burba, G.: Eddy Covariance Method for Scientific, Industrial, Agricultural and Regulatory Applications, LICOR Biosciences, Lincoln, NE, USA, 2013.
Cernusak, L. A., Hutley, L. B., Beringer, J., and Tapper, N. J.: Stem and leaf gas exchange and their responses to fire in a north Australian tropical savanna, Plant Cell Environ., 29, 632-646, 2006.

Chapin III, F. S., Woodwell, G. M., Randerson, J. T., Rastetter, E. B., Lovett, G. M., Baldocchi, D. D., Clark, D. A., Harmon, M E., Schimel, D. S., Valentini, R., Wirth, C., Aber, J. D., Cole, J. J., Goulden, M. L., Harden, J. W., Heimann, M., Howarth, R. W. Matson, P. A., McGuire, A. D., Melillo, J. M., Mooney, H. A., Neff, J. C., Houghton, R. A., Pace, M. L., Ryan, M. G., Running, S. W., Sala, O. E., Schlesinger, W. H., and Schulze, E. D.: Reconciling carbon-cycle concepts, terminology, and methods, Ecosystems, 9, 1041-1050, 2006.

Chen, X., Eamus, D., and Hutley, L. B.: Seasonal patterns of soil carbon dioxide efflux from a wet-dry tropical savanna of northern Australia, Aust. J. Bot., 50, 43-51, 2002.

Chen, X., Hutley, L. B., and Eamus, D.: Carbon balance of a tropical savanna of northern Australia, Oecologia, 137, 405-416, 2003.

Cleverly, J., Boulain, N., Villalobos-Vega, R., Grant, N., Faux, R., Wood, C., Cook, P. G., Yu, Q., Leigh, A., and Eamus, D.: Dynamics of component carbon fluxes in a semi-arid Acacia woodland, central Australia, J. Geophys. Res.-Biogeo., 118, 11681185, 2013.

Cook, G. D. and Heerdegen, R. G.: Spatial variation in the duration of the rainy season in monsoonal Australia, Int. J. Climatol., 21, 1723-1732, 2001

Cook, P. G., Hatton, T. J., Pidsley, D., Herczeg, A. L., Held, A., O'Grady, A., and Eamus, D.: Water balance of a tropical woodland ecosystem, Northern Australia: A combination of micro-meteorological, soil physical and groundwater chemical approaches, J. Hydrol., 210, 161-177, 1998.

Duff, G. A., Myers, B. A., Williams, R. J., Eamus, D., O’Grady, A., and Fordyce, I. R.: Seasonal patterns in soil moisture, vapour pressure deficit, tree canopy cover and pre-dawn water potential in a Northern Australian savanna, Aust. J. Bot., 45, 211-224, 1997.

Eamus, D.: Ecophysiological traits of deciduous and evergreen woody species in the seasonally dry tropics, Trends Ecol. Evol., 14, 11-16, 1999.

Eamus, D. and Prichard, H.: A cost-benefit analysis of leaves of four Australian savanna species, Tree Physiol., 18, 537-545, 1998.

Eamus, D., Hutley, L. B., and O'Grady, A. P.: Daily and seasonal patterns of carbon and water fluxes above a north Australian savanna, Tree Physiol., 21, 977-988, 2001.

Eamus, D., Chen, X., Kelley, G., and Hutley, L. B.: Root biomass and root fractal analyses of an open Eucalyptus forest in a savanna of north Australia, Aust. J. Bot., 50, 31-41, 2002.

Eamus, D., Cleverly, J., Boulain, N., Grant, N., Faux, R., and Villalobos-Vega, R.: Carbon and water fluxes in an arid-zone acacia savanna woodland: An analyses of seasonal patterns and responses to rainfall events, Agr. Forest Meteorol., 182-183, 225238, 2013.

Falk, M., Paw U, K. T., Wharton, S., and Schroeder, M.: Is soil respiration a major contributor to the carbon budget within a Pacific Northwest old-growth forest?, Agr. Forest Meteorol., 135, 269283, 2005.

Fox, I. D., Nelder, V. J., Wilson, G. W., and Bannik, P. J.: The vegetation of the Australian tropical savannas, Environmental Protection Agency, Brisbane, QLD, 2001. 
Garbulsky, M. F., Peñuelas, J., Papale, D., Ardö, J., Goulden, M. L., Kiely, G., Richardson, A. D., Rotenberg, E., Veenendaal, E. M., and Filella, I.: Patterns and controls of the variability of radiation use efficiency and primary productivity across terrestrial ecosystems, Global Ecol. Biogeogr., 19, 253-267, 2010.

Goulden, M. L., Munger, J. W., Song-Miao, F., Daube, B. C., and Wofsy, S. C.: Measurements of carbon sequestration by longterm eddy covariance: methods and a critical evaluation of accuracy, Glob. Change Biol., 2, 169-182, 1996.

Grace, J., José, J. S., Meir, P., Miranda, H. S., and Montes, R. A.: Productivity and carbon fluxes of tropical savannas, J. Biogeogr., 33, 387-400, 2006.

Haverd, V., Raupach, M. R., Briggs, P. R., J. G. Canadell., Davis, S. J., Law, R. M., Meyer, C. P., Peters, G. P., Pickett-Heaps, C., and Sherman, B.: The Australian terrestrial carbon budget, Biogeosciences, 10, 851-869, doi:10.5194/bg-10-851-2013, 2013.a.

Haverd, V., Raupach, M. R., Briggs, P. R., Canadell, J. G., Isaac, P., Pickett-Heaps, C., Roxburgh, S. H., van Gorsel, E., Viscarra Rossel, R. A., and Wang, Z.: Multiple observation types reduce uncertainty in Australia's terrestrial carbon and water cycles, Biogeosciences, 10, 2011-2040, doi:10.5194/bg-10-2011-2013, 2013b.

Hoffmann, W. A., Geiger, E. L., Gotsch, S. G., Rossatto, D. R., Silva, L. C. R., Lau, O. L., Haridasan, M., and Franco, A. C.: Ecological thresholds at the savanna-forest boundary: How plant traits, resources and fire govern the distribution of tropical biomes, Ecol. Lett., 15, 759-768, 2012.

Hollinger, D. Y. and Richardson, A. D.: Uncertainty in eddy covariance measurements and its application to physiological models, Tree Physiol., 25, 873-885, 2005.

House, J. I. and Hall, D. O.: Productivity of Tropical Savannas and Grasslands, in: Terrestrial Global Productivity, edited by: Roy, J., Saugier, B. and Mooney, H. A., Academic Press, San Diego, 363-400, 2001.

Hutley, L. B. and Beringer, J.: Disturbance and climatic drivers of carbon dynamics of a northern Australian tropical savanna in: Ecosystem function in savannas edited by: Hill, M. J. and Hanan, N. P., CRC Press, Florida, 2010.

Hutley, L. B., O'Grady, A. P., and Eamus, D.: Evapotranspiration from eucalypt open-forest savanna of northern australia, Funct. Ecol., 14, 183-194, 2000.

Hutley, L. B., Leuning, R., Beringer, J., and Cleugh, H. A.: The utility of the eddy covariance techniques as a tool in carbon accounting: Tropical savanna as a case study, Aust. J. Bot. 53, 663-675, 2005.

Hutley, L. B., Beringer, J., Isaac, P. R., Hacker, J. M., and Cernusak, L. A.: A sub-continental scale living laboratory: Spatial patterns of savanna vegetation over a rainfall gradient in northern Australia, Agr. Forest Meteorol., 151, 1417-1428, 2011.

Hutley, L. B., Evans, B. J., Beringer, J., Cook, G. D., Maier, S. W., and Razon, E.: Impacts of an extreme cyclone event on landscape-scale savanna fire, productivity and greenhouse gas emissions, Environ. Res. Lett., 8, 1-12, 2013.

Isbell, R. F.: The Australian Soil Classification, CSIRO Publishing, Collingwood, VIC, 1996.

Jamali, H., Livesley, S. J., Grover, S. P., Dawes, T. Z., Hutley, L. B., Cook, G. D., and Arndt, S. K.: The Importance of Termites to the $\mathrm{CH}_{4}$ Balance of a Tropical Savanna Woodland of Northern Australia, Ecosystems, 14, 698-709, 2011.
Jones, D. A., Wang, W., and Fawcett, R.: High-quality spatial climate data-sets for Australia, Australian Meteorological and Oceanographic Journal, 58, 233-248, 2009.

Kaimal, J. C. and Finnigan, J. J.: Atmospheric boundary layer flows: their structure and measurement, Oxford University Press, New York, 1994.

Kanniah, K. D., Beringer, J., Hutley, L. B., Tapper, N. J., and Zhu, X.: Evaluation of Collections 4 and 5 of the MODIS Gross Primary Productivity product and algorithm improvement at a tropical savanna site in northern Australia, Remote Sens. Environ., 113, 1808-1822, 2009.

Kanniah, K. D., Beringer, J., and Hutley, L. B.: The comparative role of key environmental factors in determining savanna productivity and carbon fluxes: A review, with special reference to Northern Australia, Prog. Phys. Geog., 34, 459-490, 2010.

Kanniah, K. D., Beringer, J., and Hutley, L. B.: Environmental controls on the spatial variability of savanna productivity in the Northern Territory, Australia, Agr. Forest Meteorol., 151, 14291439, 2011.

Kanniah, K. D., Beringer, J., and Hutley, L.: Exploring the link between clouds, radiation, and canopy productivity of tropical savannas, Agr. Forest Meteorol., 182-183, 304-313, 2013.

Keith, H., Leuning, R., Jacobsen, K. L., Cleugh, H. A., van Gorsel, E., Raison, R. J., Medlyn, B. E., Winters, A., and Keitel, C.: Multiple measurements constrain estimates of net carbon exchange by a Eucalyptus forest, Agr. Forest Meteorol., 149, 535-558, 2009.

Kelley, G., O’Grady, A. P., Hutley, L. B., and Eamus, D.: A comparison of tree water use in two contiguous vegetation communities of the seasonally dry tropics of northern Australia: The importance of site water budget to tree hydraulics, Aust. J. Bot., 55, 700-708, doi:10.1071/BT07021, 2007.

Kljun, N., Calanca, P., Rotach, M. W., and Schmid, H. P.: A simple parameterisation for flux footprint predictions, Bound.-Lay. Meteorol., 112, 503-523, 2004.

Lamaud, E., Ogée, J., Brunet, Y., and Berbigier, P.: Validation of eddy flux measurements above the understorey of a pine forest, Agr. Forest Meteorol., 106, 187-203, 2001.

Launiainen, S., Rinne, J., Pumpanen, J., Kulmala, L., Kolari, P., Keronen, P., Siivola, E., Pohja, T., Hari, P., and Vesala, T.: Eddy covariance measurements of $\mathrm{CO}_{2}$ and sensible and latent heat fluxes during a full year in a boreal pine forest trunk-space, Boreal Environ. Res., 10, 569-588, 2005.

Law, B. E., Baldocchi, D. D., and Anthoni, P. M.: Below-canopy and soil $\mathrm{CO}_{2}$ fluxes in a ponderosa pine forest, Agr. Forest Meteorol., 94, 171-188, 1999.

Lazarides, M., Hacker, J. B., and Andrew, M. H.: Taxonomy, cytology and ecology of indigenous Australian sorghums (Sorghum Moench: Andropogoneae: Poaceae), Aust. Syst. Bot., 4, 591635, 1991.

Lehmann, C. E. R., Anderson, T. M., Sankaran, M., Higgins, S. I., Archibald, S., Hoffmann, W. A., Hanan, N. P., Williams, R. J., Fensham, R. J., Felfili, J., Hutley, L. B., Ratnam, J., San Jose, J., Montes, R., Franklin, D., Russell-Smith, J., Ryan, C. M., Durigan, G., Hiernaux, P., Haidar, R., Bowman, D. M. J. S., and Bond, W. J.: Savanna vegetation-fire-climate relationships differ among continents, Science, 343, 548-552, 2014. 
Leuning, R., van Gorsel, E., Massman, W. J., and Isaac, P. R.: Reflections on the surface energy imbalance problem, Agr. Forest Meteorol., 156, 65-74, 2012.

Livesley, S. J., Grover, S., Hutley, L. B., Jamali, H., ButterbachBahl, K., Fest, B., Beringer, J., and Arndt, S. K.: Seasonal variation and fire effects on $\mathrm{CH}_{4}, \mathrm{~N}_{2} \mathrm{O}$ and $\mathrm{CO}_{2}$ exchange in savanna soils of northern Australia, Agr. Forest Meteorol., 151, 14401452, 2011.

Ma, S., Baldocchi, D. D., Xu, L., and Hehn, T.: Inter-annual variability in carbon dioxide exchange of an oak/grass savanna and open grassland in California, Agr. Forest Meteorol., 147, 157171, 2007.

Ma, X., Huete, A., Yu, Q., Coupe, N. R., Davies, K., Broich, M., Ratana, P., Beringer, J., Hutley, L. B., Cleverly, J., Boulain, N., and Eamus, D.: Spatial patterns and temporal dynamics in savanna vegetation phenology across the north australian tropical transect, Remote Sens. Environ., 139, 97-115, 2013.

Mackey, B. G., Woinarski, J. C. Z., Nix, H., and Trail, B.: The Nature of Northern Australia: Its natural values, ecology and future prospects, ANU Electronic Press, Canberra, 2007.

McHugh, I., Beringer, J., and Cunningam, S.: A 3-year record of ecosystem-atmosphere carbon exchange from a "perfect" eucalypt woodland site: controls, corrections and uncertainties, Biogeosciences, in preparation, 2016.

Misson, L., Baldocchi, D. D., Black, T. A., Blanken, P. D., Brunet, Y., Curiel Yuste, J., Dorsey, J. R., Falk, M., Granier, A., Irvine, M. R., Jarosz, N., Lamaud, E., Launiainen, S., Law, B. E., Longdoz, B., Loustau, D., McKay, M., Paw U, K. T., Vesala, T., Vickers, D., Wilson, K. B., and Goldstein, A. H.: Partitioning forest carbon fluxes with overstory and understory eddy-covariance measurements: A synthesis based on FLUXNET data, Agr. Forest Meteorol., 144, 14-31, 2007.

Mistry, J.: Savannas, Prog. Phys. Geog., 25, 552-559, 2001.

Murphy, B. P., Russell-Smith, J., and Prior, L. D.: Frequent fires reduce tree growth in northern Australian savannas: Implications for tree demography and carbon sequestration, Glob. Change Biol., 16, 331-343, 2010.

Myers, B. A., Williams, R. J., Fordyce, I., Duff, G. A., and Eamus, D.: Does irrigation affect leaf phenology in deciduous and evergreen trees of the savannas of northern Australia?, Austral Ecol., 23, 329-339, 1998.

Nemani, R. R., Keeling, C. D., Hashimoto, H., Jolly, W. M., Piper, S. C., Tucker, C. J., Myneni, R. B., and Running, S. W.: Climatedriven increases in global terrestrial net primary production from 1982 to 1999 , Science, 300, 1560-1563, 2003.

O'Grady, A. P., Eamus, D., and Hutley, L. B.: Transpiration increases during the dry season: Patterns of tree water use in eucalypt open-forests of northern Australia, Tree Physiol., 19, 591597, 1999.

O'Grady, A. P., Chen, X., Eamus, D., and Hutley, L. B.: Composition, leaf area index and standing biomass of eucalypt open forests near Darwin in the Northern Territory, Australia, Aust. J. Bot., 48, 629-638, 2000.

Papale, D., Reichstein, M., Aubinet, M., Canfora, E., Bernhofer, C., Kutsch, W., Longdoz, B., Rambal, S., Valentini, R., Vesala, T., and Yakir, D.: Towards a standardized processing of Net Ecosystem Exchange measured with eddy covariance technique: algorithms and uncertainty estimation, Biogeosciences, 3, 571-583, doi:10.5194/bg-3-571-2006, 2006.
Prior, L. D., Eamus, D., and Duff, G. A.: Seasonal and diurnal patterns of carbon assimilation, stomatal conductance and leaf water potential in Eucalyptus tetrodonta saplings in a wet-dry savanna in northern australia, Aust. J. Bot., 45, 241-258, 1997.

Prior, L. D., Eamus, D., and Bowman, D. M. J. S.: Tree growth rates in north Australian savanna habitats: Seasonal patterns and correlations with leaf attributes, Aust. J. Bot., 52, 303-314, 2004.

Prior, L. D., Brook, B. W., Williams, R. J., Werner, P. A., Bradshaw, C. J. A., and Bowman, D. M. J. S.: Environmental and allometric drivers of tree growth rates in a north Australian savanna, Forest Ecol. Manag., 234, 164-180, 2006.

Pumpanen, J., Kolari, P., Ilvesniemi, H., Minkkinen, K., Vesala, T., Niinistö, S., Lohila, A., Larmola, T., Morero, M., Pihlatie, M., Janssens, I., Yuste, J. C., Grünzweig, J. M., Reth, S., Subke, J. A., Savage, K., Kutsch, W., Østreng, G., Ziegler, W., Anthoni, P., Lindroth, A., and Hari, P.: Comparison of different chamber techniques for measuring soil $\mathrm{CO}_{2}$ efflux, Agr. Forest Meteorol., 123, 159-176, 2004.

Reichstein, M., Falge, E., Baldocchi, D., Papale, D., Aubinet, M., Berbigier, P., Bernhofer, C., Buchmann, N., Gilmanov, T., Granier, A., Grünwald, T., Havránková, K., Ilvesniemi, H., Janous, D., Knohl, A., Laurila, T., Lohila, A., Loustau, D., Matteucci, G., Meyers, T., Miglietta, F., Ourcival, J. M., Pumpanen, J., Rambal, S., Rotenberg, E., Sanz, M., Tenhunen, J., Seufert, G., Vaccari, F., Vesala, T., Yakir, D., and Valentini, R.: On the separation of net ecosystem exchange into assimilation and ecosystem respiration: Review and improved algorithm, Glob. Change Biol., 11, 1424-1439, 2005.

Richards, A. E., Dathe, J., and Cook, G. D.: Fire interacts with season to influence soil respiration in tropical savannas, Soil Biol. Biochem., 53, 90-98, 2012.

Roderick, M. L., Farquhar, G. D., Berry, S. L., and Noble, I. R.: On the direct effect of clouds and atmospheric particles on the productivity and structure of vegetation, Oecologia, 129, 21-30, 2001.

Russell-Smith, J. and Yates, C. P.: Australian savanna fire regimes: context, scales, patchiness, Fire Ecology, 3, 48-63, 2007.

Ryu, Y., Baldocchi, D. D., Kobayashi, H., Van Ingen, C., Li, J., Black, T. A., Beringer, J., Van Gorsel, E., Knohl, A., Law, B. E., and Roupsard, O.: Integration of MODIS land and atmosphere products with a coupled-process model to estimate gross primary productivity and evapotranspiration from $1 \mathrm{~km}$ to global scales, Global Biogeochem. Cy., 25, GB4017, doi:10.1029/2011GB004053, 2011.

Sankaran, M., Ratnam, J., and Hanan, N. P.: Tree-grass coexistence in savannas revisited - Insights from an examination of assumptions and mechanisms invoked in existing models, Ecol. Lett., 7, 480-490, 2004.

Sankaran, M., Hanan, N. P., Scholes, R. J., Ratnam, J., Augustine, D. J., Cade, B. S., Gignoux, J., Higgins, S. I., Le Roux, X., Ludwig, F., Ardo, J., Banyikwa, F., Bronn, A., Bucini, G., Caylor, K. K., Coughenour, M. B., Diouf, A., Ekaya, W., Feral, C. J., February, E. C., Frost, P. G. H., Hiernaux, P., Hrabar, H., Metzger, K. L., Prins, H. H. T., Ringrose, S., Sea, W., Tews, J., Worden, J., and Zambatis, N.: Determinants of woody cover in African savannas, Nature, 438, 846-849, 2005.

Sarimento, G.: Biodiversity and Water Relations in Tropical Savannas, in: Biodiversity and Savanna Ecosystem Processes, edited 
by: Solbrig, O. T., Medina, E., and Silva, J. F., Springer, Germany, 1996.

Saugier, B., Roy, J., and Mooney, H. A.: Estimations of Global Terrestrial Productivity: Converging toward a Single Number?, in: Terrestrial Global Productivity, edited by: Roy, J., Saugier, B., and Mooney, H. A., Academic Press, San Diego, 543-557, 2001.

Scheiter, S. and Higgins, S. I.: Impacts of climate change on the vegetation of Africa: An adaptive dynamic vegetation modelling approach, Glob. Change Biol., 15, 2224-2246, 2009.

Scheiter, S., Higgins, S. I., Beringer, J., and Hutley, L. B.: Climate change and long-term fire management impacts on Australian savannas, New Phytol., 205, 1211-1226, 2015.

Scholes, R. J. and Archer, S. R.: Tree-grass interactions in Savannas, Annu. Rev. Ecol. Syst., 28, 517-544, 1997.

Setterfield, S. A. and Williams, R. J.: Patterns of flowering and seed production in Eucalyptus miniata and E. tetrodonta in a tropical Savanna Woodland, Northern Australia, Aust. J. Bot., 44, 107122, 1996.

Shackleton, S. E., Shackleton, C. M., Netshiluvhi, T. R., Geach, B. S., Ballance, A., and Fairbanks, D. H. K.: Use patterns and value of savanna resources in three rural villages in South Africa, Econ. Bot., 56, 130-146, 2002.

Spangler, R. E.: Taxonomy of Sarga, Sorghum and Vacoparis (Poaceae: Andropogoneae), Aust. Syst. Bot., 16, 279-299, 2003.

Staben, G. W. and Evans, K. G.: Estimates of tree canopy loss as a result of Cyclone Monica, in the Magela Creek catchment northern Australia, Austral Ecol., 33, 562-569, 2008.

Stoy, P. C., Mauder, M., Foken, T., Marcolla, B., Boegh, E., Ibrom, A., Arain, M. A., Arneth, A., Aurela, M., Bernhofer, C., Cescatti, A., Dellwik, E., Duce, P., Gianelle, D., van Gorsel, E., Kiely, G., Knohl, A., Margolis, H., McCaughey, H., Merbold, L., Montagnani, L., Papale, D., Reichstein, M., Saunders, M., Serrano-Ortiz, P., Sottocornola, M., Spano, D., Vaccari, F., and Varlagin, A.: A data-driven analysis of energy balance closure across FLUXNET research sites: The role of landscape scale heterogeneity, Agr. Forest Meteorol., 171-172, 137-152, 2013.

van der Werf, G. R., Randerson, J. T., Giglio, L., Collatz, G. J., Mu, M., Kasibhatla, P. S., Morton, D. C., DeFries, R. S., Jin, Y., and van Leeuwen, T. T.: Global fire emissions and the contribution of deforestation, savanna, forest, agricultural, and peat fires (19972009), Atmos. Chem. Phys., 10, 11707-11735, doi:10.5194/acp10-11707-2010, 2010.

van Gorsel, E., Delpierre, N., Leuning, R., Black, A., Munger, J. W., Wofsy, S., Aubinet, M., Feigenwinter, C., Beringer, J., Bonal, D., Chen, B., Chen, J., Clement, R., Davis, K. J., Desai, A. R., Dragoni, D., Etzold, S., Grünwald, T., Gu, L., Heinesch, B., Hutyra, L. R., Jans, W. W. P., Kutsch, W., Law, B. E., Leclerc, M. Y., Mammarella, I., Montagnani, L., Noormets, A., Rebmann, C., and Wharton, S.: Estimating nocturnal ecosystem respiration from the vertical turbulent flux and change in storage of $\mathrm{CO}_{2}$, Agr. Forest Meteorol., 149, 1919-1930, 2009.
Watkinson, A. R. and Powell, J. C.: The life history and population structure of Cycas armstrongii in monsoonal northern Australia, Oecologia, 111, 341-349, 1997.

Webb, E. K., Pearman, G. I., and Leuning, R.: Correction of flux measurements for density effects due to heat and water vapour transfer, Q. J. Roy. Meteor. Soc., 106, 85-100, 1980.

Werner, P. A.: Growth of juvenile and sapling trees differs with both fire season and understorey type: Trade-offs and transitions out of the fire trap in an Australian savanna, Austral Ecol., 37, 644657, 2012.

Werner, P. A. and Franklin, D. C.: Resprouting and mortality of juvenile eucalypts in an Australian savanna: Impacts of fire season and annual sorghum, Aust. J. Bot., 58, 619-628, 2010.

Werner, P. A. and Prior, L. D.: Tree-piping termites and growth and survival of host trees in savanna woodland of north Australia, J. Trop. Ecol., 23, 611-622, 2007.

Werner, P. A. and Prior, L. D.: Demography and growth of subadult savanna trees: Interactions of life history, size, fire season, and grassy understory, Ecol. Monog., 83, 67-93, 2013.

Werner, P. A., Cowie, I. D., and Cusack, J. S.: Juvenile tree growth and demography in response to feral water buffalo in savannas of northern Australia: An experimental field study in Kakadu National Park, Aust. J. Bot., 54, 283-296, 2006.

Whitley, R. J., Macinnis-Ng, C. M. O., Hutley, L. B., Beringer, J., Zeppel, M., Williams, M., Taylor, D., and Eamus, D.: Is productivity of mesic savannas light limited or water limited? Results of a simulation study, Glob. Change Biol., 17, 3130-3149, 2011.

Williams, M., Rastetter, E. B., Fernandes, D. N., Goulden, M. L., Wofsy, S. C., Shaver, G. R., Melillo, J. M., Munger, J. W., Fan, S. M., and Nadelhoffer, K. J.: Modelling the soil-plant-atmosphere continuum in a Quercus-acer stand at Harvard forest: The regulation of stomatal conductance by light, nitrogen and soil/plant hydraulic properties, Plant, Cell Environment, 19, 911-927, 1996.

Williams, R. J., Myers, B. A., Muller, W. J., Duff, G. A., and Eamus, D.: Leaf phenology of woody species in a North Australian tropical savanna, Ecology, 78, 2542-2558, 1997.

Williams, R. J., Hutley, L. B., Cook, G. D., Russell-Smith, J., Edwards, A., and Chen, X.: Assessing the carbon sequestration potential of mesic savannas in the Northern Territory, Australia: Approaches, uncertainties and potential impacts of fire, Funct. Plant Biol., 31, 415-422, 2004. 